\title{
Stratospheric temperature trends: impact of ozone variability and the QBO
}

\author{
Mauro Dall'Amico • Lesley J. Gray • \\ Karen H. Rosenlof • Adam A. Scaife • \\ Keith P. Shine - Peter A. Stott
}

Received: 31 July 2008/Accepted: 28 May 2009/Published online: 18 July 2009

(C) Crown Copyright 2009

\begin{abstract}
In most climate simulations used by the Intergovernmental Panel on Climate Change 2007 fourth assessment report, stratospheric processes are only poorly represented. For example, climatological or simple specifications of time-varying ozone concentrations are imposed and the quasi-biennial oscillation (QBO) of equatorial stratospheric zonal wind is absent. Here we investigate the impact of an improved stratospheric representation using two sets of perturbed simulations with the Hadley Centre coupled ocean atmosphere model HadGEM1 with natural and anthropogenic forcings for the 1979-2003 period. In the first set of simulations, the usual zonal mean ozone climatology with superimposed trends is replaced with a time series of observed zonal mean ozone distributions that includes interannual variability associated with the solar
\end{abstract}

M. Dall'Amico $(\bowtie)$ L. J. Gray

NCAS Climate, Department of Meteorology,

University of Reading, Reading, UK

e-mail: Mauro.DallAmico@dlr.de

Present Address:

M. Dall'Amico

Deutsches Zentrum für Luft-und Raumfahrt, Institut für Physik der Atmosphäre,

Oberpfaffenhofen, Germany

K. H. Rosenlof

NOAA Earth System Research Laboratory, Boulder, CO, USA

A. A. Scaife

Met Office Hadley Centre, Exeter, UK

K. P. Shine

Department of Meteorology, University of Reading,

Reading, UK

P. A. Stott

Met Office Hadley Centre, Exeter, UK cycle, QBO and volcanic eruptions. In addition to this, the second set of perturbed simulations includes a scheme in which the stratospheric zonal wind in the tropics is relaxed to appropriate zonal mean values obtained from the ERA-40 re-analysis, thus forcing a QBO. Both of these changes are applied strictly to the stratosphere only. The improved ozone field results in an improved simulation of the stepwise temperature transitions observed in the lower stratosphere in the aftermath of the two major recent volcanic eruptions. The contribution of the solar cycle signal in the ozone field to this improved representation of the stepwise cooling is discussed. The improved ozone field and also the QBO result in an improved simulation of observed trends, both globally and at tropical latitudes. The Eulerian upwelling in the lower stratosphere in the equatorial region is enhanced by the improved ozone field and is affected by the QBO relaxation, yet neither induces a significant change in the upwelling trend.

Keywords All-forcings simulations of recent climate assessed by the IPCC 2007 AR4 - Observed zonal mean ozone distributions - QBO of stratospheric equatorial zonal wind · 11-year solar cycle · Volcanic eruptions of El Chichón and Mt. Pinatubo · Variability and trends of stratospheric temperatures

\section{Introduction}

It is now well established that there has been a warming of the Earth's surface and lower atmosphere over the past 50 years with an accompanying cooling of the stratosphere (Intergovernmental Panel on Climate Change 2007 Fourth Assessment Report, henceforth AR4). An important test of climate models is how well they are able to reproduce 
observed changes in the atmosphere, particularly those in the past three decades during which extensive satellite observations have become available. Inherent in all analyses of both model simulations and observations is the problem of distinguishing human-induced changes from those that might have occurred naturally, associated for example with solar variations, volcanic activity and the natural internal variability of the climate system.

Ozone loss in the stratosphere in recent decades is thought to be a major contributor to the observed stratospheric cooling (e.g. Shine et al. 2003; Ramaswamy et al. 2006; Eyring et al. 2006), tropopause height increase (e.g. Santer et al. 2003; Seidel and Randel 2006) and also Southern Hemisphere (SH) surface temperature and circulation changes (Thompson and Solomon 2002; Gillett and Thompson 2003). Despite the growing evidence for the influence of stratospheric ozone on temperature trends, many of the simulations of recent climate assessed by the AR4 did not include an ozone trend (Cordero and Forster 2006). Among the simulations that did include a trend, the simulations conducted by the UK Met Office Hadley Centre used a zonal mean ozone climatology with superimposed trends (Stott et al. 2006). However, well-known ozone variations associated with, for example, the solar cycle (e.g. Randel and $\mathrm{Wu}$ 2007), the quasi-biennial oscillation (QBO; e.g. Gray and Pyle 1989; Baldwin et al. 2001), volcanic eruptions (Randel and Wu 1995) as well as internal variability due to e.g. changes in wave driving were not included. Thus, although irradiance changes associated with the 11-year solar cycle and volcanic eruptions (direct effects) are specifically represented in many of the climate models and fed through to the models' radiation schemes, the indirect effects due to the associated ozone changes are not represented (e.g. Stott et al. 2001).

The recent observational study of Thompson and Solomon (2009) suggested that the stepwise cooling of the lower stratosphere observed in the aftermath of the volcanic eruptions of El Chichón in February/March 1982 and Mt. Pinatubo in June 1991 (Pawson et al. 1998; Seidel and Lanzante 2004) is primarily caused by the radiative and ozone effects of volcanic aerosol. Interannual ozone variations associated with the 11-year solar cycle, volcanic eruptions and the QBO cause corresponding variations in heating rates and hence temperature changes in the lower stratosphere which may influence the troposphere (Haigh 2003; Crooks and Gray 2005; Haigh et al. 2005). Recent model studies have suggested that the inclusion of more realistic ozone variations may be an important factor in the accurate simulation of the solar cycle influence (Austin et al. 2008; Gray et al. 2009), the effects of which could be underestimated by models that do not include these processes in the past (Stott et al. 2003).
In addition, the models employed for the AR4 do not generally include the QBO (see Randall et al. 2007, Sect. 8.4.9), which means that stratospheric variability, particularly in the tropical region, will be severely underestimated. There is some evidence that changes in lower stratospheric equatorial temperatures associated with the QBO influence the underlying troposphere (e.g. Collimore et al. 1998, 2003, Giorgetta et al. 1999; Baldwin et al. 2001). Also high latitude changes of the stratospheric polar vortex are thought to impact mid and high latitude tropospheric weather and climate, for example through changes in the North Atlantic Oscillation and position of the jet stream (Thompson and Wallace 2000; Coughlin and Tung 2001; Baldwin et al. 2003; Dall'Amico and Egger 2007). Stenchikov et al. $(2004,2006)$ have shown that inclusion of the equatorial QBO influences the high latitude volcanic response in the stratosphere and also at the surface.

The goal of this paper is to investigate the impact of observed ozone variability and the QBO on stratospheric temperature trends in climate simulations of the late 20th century of the type conducted for the AR4. In Sect. 2, the model and methodology are described. Section 3 describes highlights of the results of this study that concern variability and trends in the stratosphere. A discussion of changes in variability and trends at the tropopause and in the troposphere, particularly near the surface, will be described in a separate paper (Dall'Amico et al. 2009). Section 4 summarises our conclusions.

\section{Model simulations}

\subsection{The model}

The study employed the Hadley Centre global environmental model version 1 (HadGEM1) described by Martin et al. (2006), Ringer et al. (2006) and Johns et al. (2006). The horizontal resolution of the atmospheric component is $1.25^{\circ}$ latitude by $1.875^{\circ}$ longitude and the model has 38 vertical levels from the surface to about $39 \mathrm{~km}$. The oceanic component of the model has a horizontal resolution of $1^{\circ}$ (the meridional resolution is $1^{\circ}$ between the poles and $30^{\circ}$ latitude, from which it increases smoothly to $1 / 3^{\circ}$ at the equator) and 40 vertical levels.

In this paper, we compare an ensemble of reference climate simulations, referred to as the 'baseline', with two ensembles of perturbed simulations. The simulations cover the 25-year period between 1 December 1978 and 1 December 2003 and include changes in well mixed greenhouse gases, tropospheric and stratospheric ozone, aerosols, land use, solar irradiance and stratospheric volcanic aerosols. The implementation of these forcings into the model is described in detail in Stott et al. (2006) and 
summarised in the next section. The representation of stratospheric ozone used in the perturbed sets of simulations is described in Sect. 2.2 and in Appendix A and B. All ensembles included three members each and used the same set of three initial conditions derived as follows. A set of three pre-industrial states were taken 85,330 and 550 years into a long control run with pre-industrial greenhouse gas concentrations described in Stott et al. (2006). Given that about two model centuries elapsed between the sampling of each of these pre-industrial states, both the atmospheric (including soil) and the oceanic (including sea ice) states may be considered to represent unrelated distinct states of the climate system. The time of these restart files was then reset to 0 UTC on 1 December 1859 and all-forcings simulations were started from these pre-industrial initial conditions, leading to the atmospheric and oceanic states for 1 December 1978.

\section{2 'Baseline' simulations}

The set-up of the baseline simulations includes natural (solar irradiance variations and volcanic eruptions) as well as anthropogenic forcings (changes in greenhouse gas concentrations, aerosol emissions and ozone trends) and is described in detail in Stott et al. (2006). The only differences between our baseline simulations and the simulations for the corresponding time period described in Stott et al. (2006) arise from a different computing environment and some recent minor bug fixes.

Concentrations of $\mathrm{CO}_{2}, \mathrm{CH}_{4}, \mathrm{~N}_{2} \mathrm{O}$ and a subset of halocarbon species up to the year 2000 are specified from the 'Ensemble-based Prediction of Climate Change and their Impacts' research theme (RT) 2A Web site (available at http://www.cnrm.meteo.fr/ensembles/) and concentrations after 2000 follow those specified by the 'Special Report on Emission Scenarios' A1B scenario (Nakicenovic and Swart 2000).

The atmospheric component of HadGEM1 includes the fully interactive modelling of atmospheric aerosols, represented by sulphate, black carbon, biomass smoke and sea salt (Martin et al. 2006). Volcanic forcing is represented by a sulphate aerosol mass mixing ratio derived from Sato et al. (1993, 2002), averaged over four equal-area latitudinal zones $\left(90^{\circ}-30^{\circ} \mathrm{S}, 30^{\circ}-0^{\circ} \mathrm{S}, 0^{\circ}-30^{\circ} \mathrm{N}, 30^{\circ}-90^{\circ} \mathrm{N}\right)$ and spread evenly across the model levels above the tropopause (see Stott et al. 2006, their page 2768). The time series is dominated by the explosive eruptions of El Chichón and Mt. Pinatubo. We note that while the variations in optical depth are included, the ozone changes associated with the volcanic eruptions are not.

A similar partial treatment of the solar forcing is also included i.e. the solar irradiance changes are prescribed but the associated ozone changes in the baseline simulations are not. Estimates of the annual mean total solar irradiance (TSI) changes from Solanki and Krivova (2003) are employed. The incoming solar shortwave radiation is partitioned in the model across six spectral bands covering the wavelength range $0.2-10 \mu \mathrm{m}$ (Stott et al. 2006; Martin et al. 2006; Johns et al. 2006). To take changes in spectral distribution of irradiance into account, a fit was made to the estimated spectral distribution change of Lean et al. (1995), and the fraction of irradiance in each of the model shortwave bands varied as the TSI varied (see Stott et al. 2006 for further details).

The model does not include an interactive chemistry scheme and therefore ozone concentrations required in the radiative calculations are externally imposed. Up to 1990, The SPARC (Stratospheric Processes and their Role in Climate) monthly mean ozone trend dataset was employed (Randel and Wu 1999; Randel et al. 1999; Kiehl et al. 1999; see also the SPARC Newsletter article by Karoly 2000). After 1990, the imposed ozone trends assumed a linear relationship between effective equivalent stratospheric chlorine (EESC) and ozone changes (Daniel et al. 1995). The burdens of ozone-depleting halogens contributing to EESC were assessed as in Montzka et al. (1999). The top panel of Fig. 1 shows the baseline ozone at $30 \mathrm{hPa}$ for the modelled period 1979-2003. This ozone time series is very smooth with almost identical repeated annual cycles and no interannual variations apart from the trends. Tropospheric ozone fields were computed using an offline chemistry transport model (Collins et al. 1997) coupled to the atmospheric component of HadGEM1, with sea ice and sea surface temperatures taken from earlier HadCM3 results (see Stott et al. 2006 for further details).

\section{3 'Baseline+ozone' simulations}

In the first ensemble of perturbed simulations, the "baseline+ozone' simulations, the set-up is the same as for the baseline except for the use in the stratosphere of an improved ozone dataset which includes observed variability. In the second ensemble of perturbed simulations, the 'baseline+ozone+QBO' simulations, the set-up is the same as for the 'baseline+ozone' and in addition to the observed zonal mean stratospheric ozone distributions, the zonal wind in the tropics is relaxed to appropriate QBO values obtained from the ERA-40 re-analysis (Uppala et al. 2005). Although the baseline+ozone simulations include the QBO in ozone, this part of the QBO, in isolation, will generate only a modest $\mathrm{QBO}$ in other components. Li et al. (1995) estimated that the diabatic warming generated by the ozone QBO contributes approximately $25 \%$ of the temperature QBO and $10 \%$ of the zonal-wind QBO.

In the 'baseline+ozone' simulations, instead of the usual ozone climatology plus superimposed trends, the 

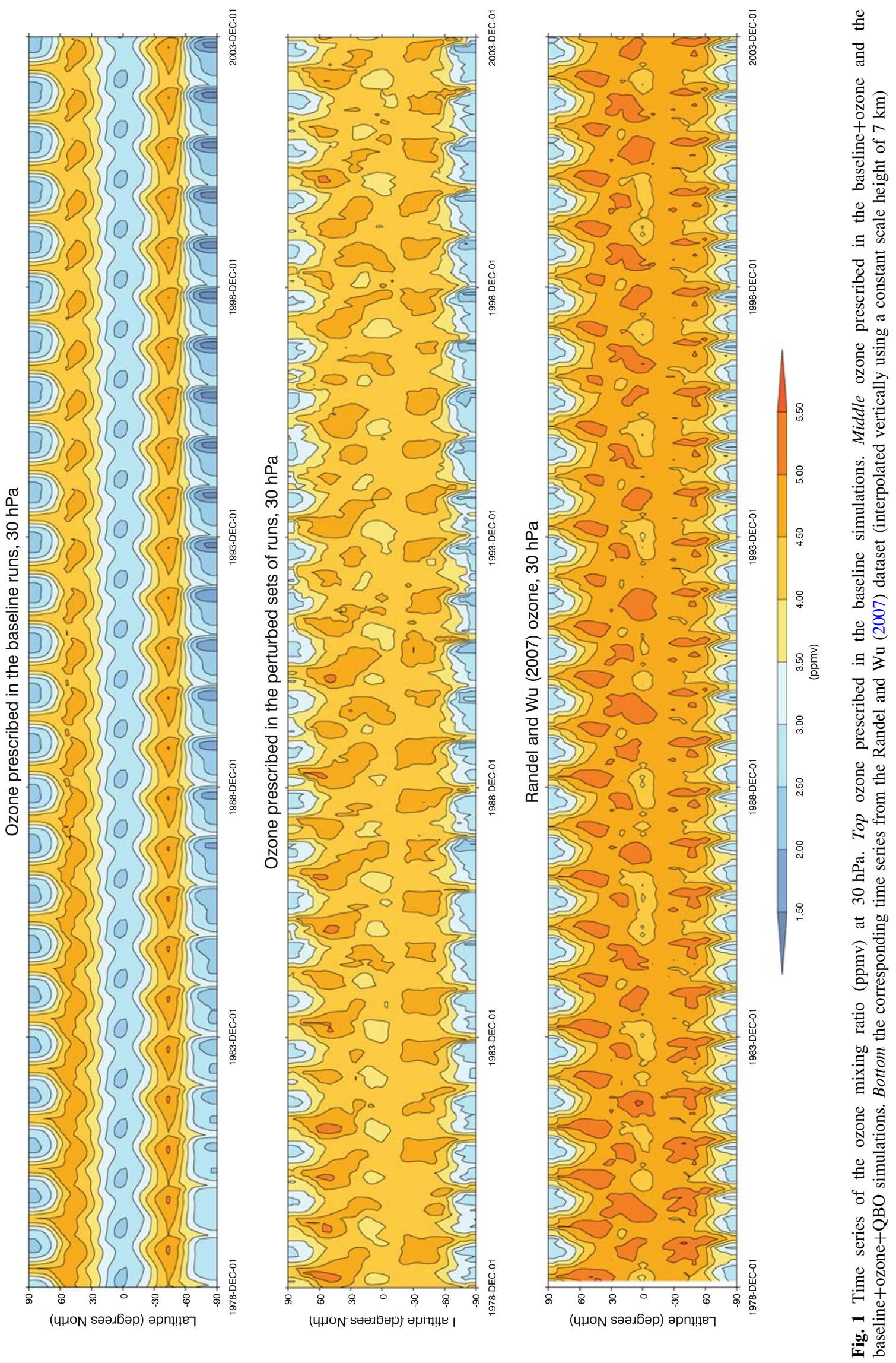
stratospheric part of the imposed ozone distributions is from a time series recently developed from a variety of satellite observations ${ }^{1}$ from a variety of different instruments. ${ }^{2}$ Data were employed from SME (solar mesosphere explorer) (Rusch et al. 1984; Thomas et al. 1984), SAGE II (stratospheric aerosol and gas experiment) (McCormick et al. 1989), HALOE (halogen occultation experiment) (Russell et al. 1993), MLS (microwave limb sounder) (Livesey et al. 2003), merged SBUV (solar backscatter ultraviolet instrument) and TOMS data (TOMS \& SBUV web site for merged dataset: http://hyperion.gsfc.nasa.gov/ Data_services/merged) (Heath et al. 1975); the data merger is described in Stolarski and Frith (2006). The middle panel of Fig. 1 shows the time series of this new ozone dataset at $30 \mathrm{hPa}$. In this dataset, there is substantial interannual variability evident at all latitudes-note e.g. the effect of the SH sudden warming event of September 2002. This provides the model with an improved time series of ozone that includes the possibility of interannual variability associated with e.g. the 11-year solar cycle, volcanic eruptions and the QBO. These simulations can be considered as a modelling counterpart of the recent observational study by Thompson and Solomon (2009).

The middle panel of Fig. 1 reports the improved ozone timeseries at $30 \mathrm{hPa}$. Tropical ozone values in the improved ozone dataset (middle panel of Fig. 1) are generally higher than the baseline ozone (top panel) by about 1 ppmv. The differences in mean ozone between the panels in Fig. 1 [the bottom panel reports the Randel and $\mathrm{Wu}$ (2007) dataset] may be associated with the strong vertical gradients in ozone mixing ratio at $30 \mathrm{hPa}$. Comparisons at a single pressure level will be prone to highlighting small differences in the vertical profile between different datasets. Also different approaches towards vertical interpolation between different grids may affect the vertical distribution as discussed in Appendix B. Note that in the lower stratosphere, global negative ozone trends over the time period considered are stronger in the baseline ozone dataset than in the improved ozone.

Figure 2 reports differences in climatological ozone distributions for January (upper panel) and July (lower panel). The improved ozone dataset prescribed in the perturbed sets of simulations has higher ozone concentrations in the tropics in the range $20-30 \mathrm{~km}$ height as well as above $20 \mathrm{~km}$ in Northern Hemisphere (NH) mid-high

\footnotetext{
1 The new ozone time series is described in detail in Appendix A. Appendix B describes how the tropospheric ozone of the baseline dataset and the stratospheric part of the new ozone time series were merged to produce the dataset used for the perturbed set of simulations.

2 The original dataset included a tropospheric ozone climatology which was adjusted to match the TOMS (total ozone mapping spectrometer) satellite observations of total column amounts.
}
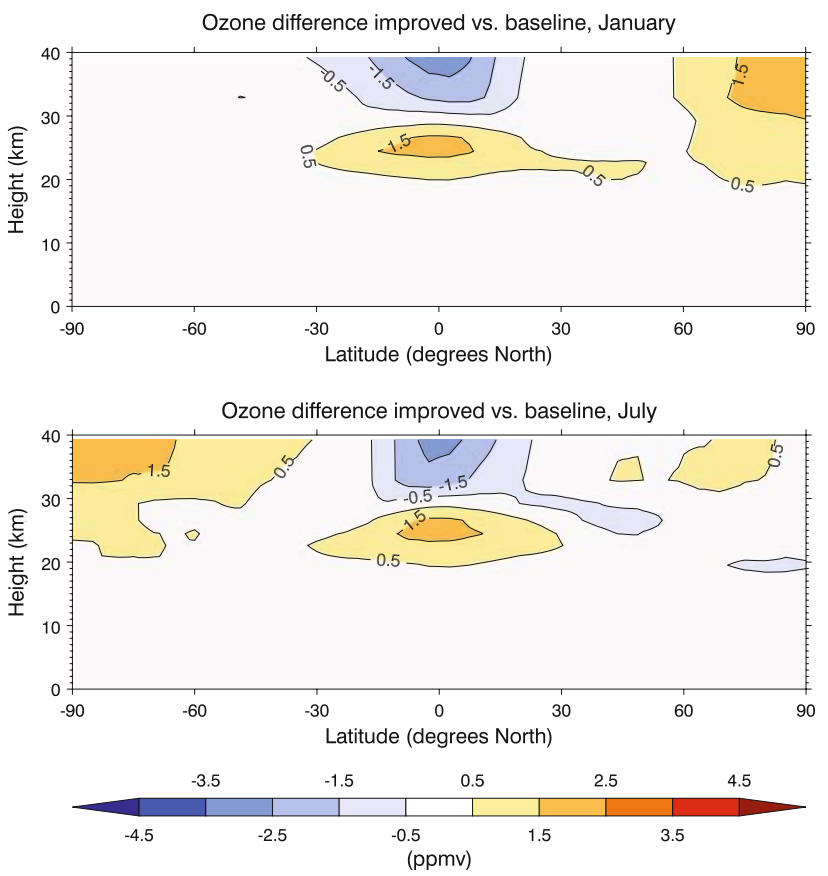

Fig. 2 Climatological ozone differences (ppmv) between the improved ozone dataset and the ozone prescribed in the baseline runs (improved ozone minus baseline ozone). Upper panel January. Lower July

latitudes in January and in SH mid-high latitudes in July. The baseline dataset has higher ozone values in the tropics above $30 \mathrm{~km}$. The changes in climatological ozone seen in Fig. 2 have a significant impact, as evident from Fig. 3 which shows the corresponding differences in January and July temperatures and zonal winds. In Fig. 3, the information is limited to grid boxes where the differences are significant with a $P$ value smaller than 0.100 according to a $t$ test conducted in the following way. The variance of an ensemble-mean value is one-third of the variance calculated across the values from the three ensemble members. The number of degrees of freedom is estimated from the data as in von Storch and Zwiers 1999, Sect. 6.6.5. The null hypotheses are that the ensemble-mean zonal mean temperatures and zonal winds are consistent across the two sets of simulations. The $P$ value represents the chance of obtaining such a difference if the null hypothesis is true. Note that the changes penetrate into the tropical troposphere which warms by about $0.4 \mathrm{~K}$ in the $7-15 \mathrm{~km}$ height range. The changes in zonal wind profile are mainly associated with changes in location and strength of the easterly and westerly stratospheric jets. This could be a response to changed heating distributions due to different climatological ozone distributions or it could be an indirect response to the changed ozone variability which can also influence wave propagation and hence jet strength and position. However, the internal variability $s$ (i.e. the standard deviation of the ensemble members around their 

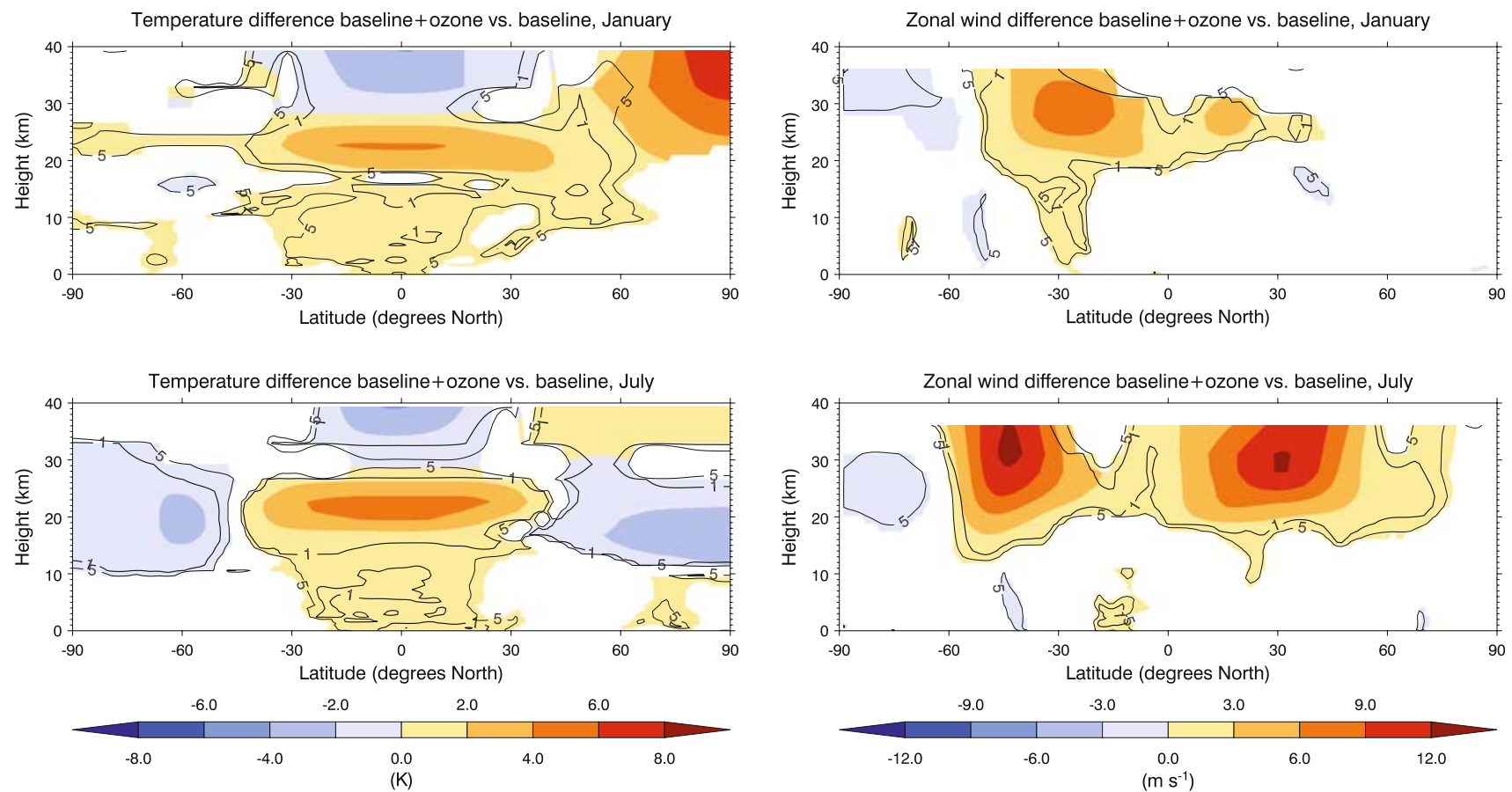

Fig. 3 Climatological differences between the baseline+ozone and the baseline ensemble-mean zonal mean temperature (left panels) and zonal wind (right) for January (upper panels) and July (lower). The

information is limited to grid boxes where the differences have a $P$ value below 0.100 . The black contour lines give the 0.050 and 0.010 $P$ value isolines (thin and thicker, respectively, contour values in \%)

mean) does not change significantly between the baseline, $s=0.165 \mathrm{~K}$, and the baseline+ozone simulations, $s=0.154 \mathrm{~K}$, as can be seen in the upper panel of Fig. 4 for the global mean temperature at $30 \mathrm{hPa}$. This also applies to the dynamically more active Arctic region ${ }^{3}$ in boreal winter (lower panel), with $s=3.075 \mathrm{~K}$ for the baseline runs and $s=3.531 \mathrm{~K}$ for the baseline+ozone simulations. Hence, the changes in the imposed ozone fields do not appear to have significantly affected the internal variability of stratospheric temperatures, despite the fact that the improved ozone fields have much greater variability than those employed in the baseline runs. This suggests that interannual variability in ozone plays only a small role in driving internal variability in temperature.

Since the improved ozone dataset has been compiled using multiple instruments and techniques, there is explicit information from the SBUV and MLS instruments in the years immediately after the El Chichón and Mt. Pinatubo eruptions. Note that some SBUV tropical data are missing for about a year after the El Chichón eruption and a

\footnotetext{
${ }^{3}$ In this paper, averages over the Arctic region refer to area-mean averages over those gridpoints located poleward of the Arctic circle (about $66.5^{\circ} \mathrm{N}$ ) and averages over the extratropical regions refer to gridpoints located poleward of the tropics (about $23.5^{\circ} \mathrm{S}-23.5^{\circ} \mathrm{N}$ ). Likewise, averages over the tropical region refer to gridpoints located between the tropics, while the equatorial region implies a latitude belt of half the width of the tropical one and centered at the equator.
}

climatology had to be used to fill in missing data. For a 2year period following the Mt. Pinatubo eruption, the SAGE-II data and some of the tropical HALOE data are unavailable. The Randel and Wu (2007) ozone dataset (bottom panel of Fig. 1) used only the SAGE-I and II datasets and therefore had a 2-year data gap after both eruptions. Because of these gaps, Randel and $\mathrm{Wu}$ employed a multiple regression technique that evaluated the trend, solar cycle and QBO variations using the available data periods and then reconstructed the full time series using these regression coefficients. As expected from the regression method employed, the time evolution is relatively smooth and shows less interannual variability than the ozone data employed in the current study (middle panel).

\section{4 'Baseline+ozone+QBO’ simulations}

In addition to including the dataset with observed stratospheric ozone variability described in the previous section, in the 'baseline+ozone+QBO' simulations, the zonal winds in the stratosphere are relaxed towards the appropriate monthly mean zonal mean values taken from the ERA-40 re-analysis (Uppala et al. 2005), thus generating a realistic QBO. The approach is similar to that first employed by Gray and Ruth (1993), see also Hamilton (1998) and Pascoe et al. (2005). At the end of each time-step the increment to the zonal wind is modified in the following way: 


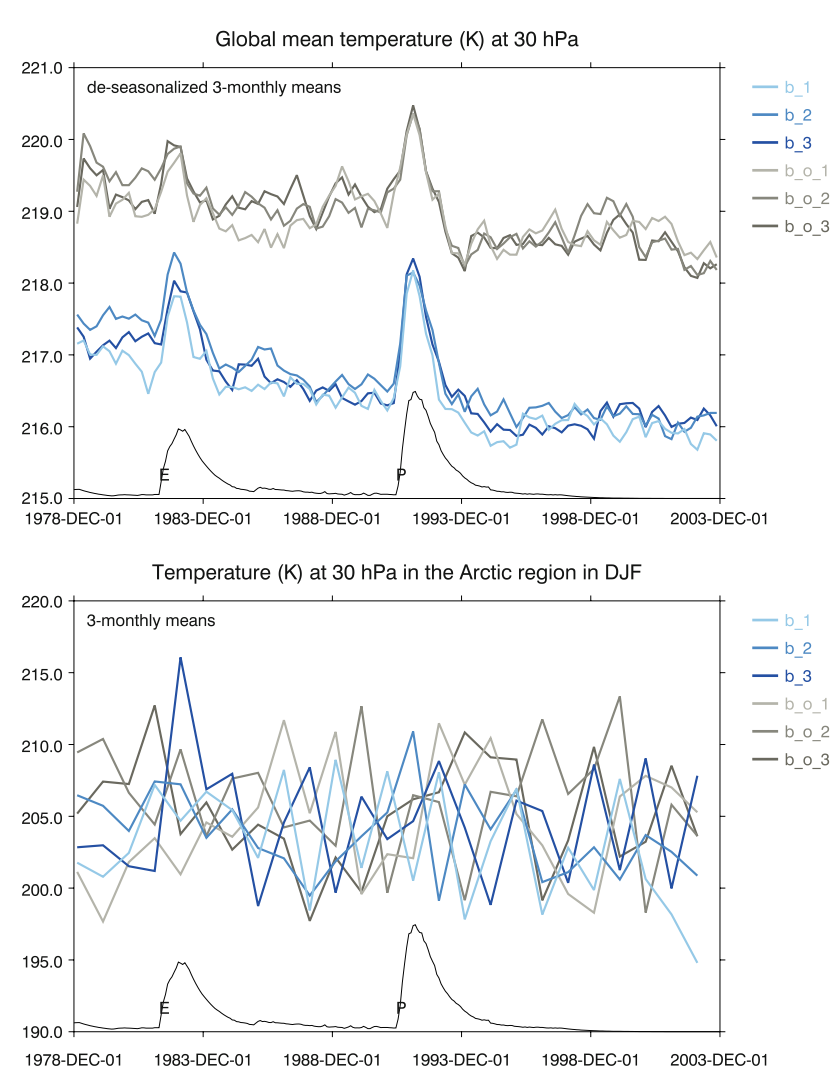

Fig. 4 Upper panel time series of global mean temperature (K) at $30 \mathrm{hPa}$ from the baseline (blue tones) and the baseline+ozone (grey tones) simulations. Lower same as top but for the Arctic region in DJF. The thin black line gives a non-dimensional measure of volcanic aerosol optical depth, showing the El Chichón $(E)$ and Mt. Pinatubo $(P)$ eruptions

$u(t+\Delta t)-u(t)=\cdots-\Delta t \alpha\left(u(t)-\beta \bar{u}_{E R A-40}(h, t)\right)$

where $\Delta t$ is the timestep, $u$ is the zonal wind at any grid point and $h$ is the height in $\mathrm{km}$. The relaxation rate $\alpha$ depends on height and latitude with

$\alpha(h, \phi)=\frac{1}{4.3 d} \exp \left(-\ln \left(\frac{0.5}{4.3}\right) \frac{(h-18.5)}{(40-18.5)}\right) \gamma(\phi)$

where $d$ is the length of the day and $\varphi$ is the latitude angle in degrees $(\varphi=0$ at the equator) with

$\gamma(\phi)=\exp \left(-2\left(\frac{\phi}{16}\right)^{2}\right)$

so that the relaxation time scale at the equator decays smoothly from 4.3 days at $18.5 \mathrm{~km}$ toward 0.5 days at $40 \mathrm{~km}$. This height-dependence of the relaxation time scale is similar to that employed by previous studies (Gray and Ruth 1993; Pascoe et al. 2005) in order to achieve a realistic wind evolution. No relaxation is applied at model levels below $18.5 \mathrm{~km}$.

The reference zonal mean zonal wind value at the equator $\bar{u}_{E R A-40}(h, t)$ is estimated from ERA-40 in the

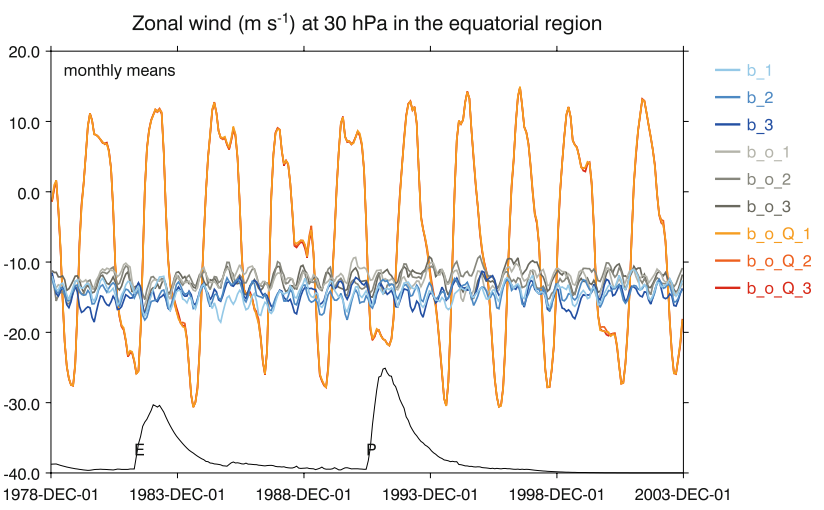

Fig. 5 Time series of monthly mean zonal wind $\left(\mathrm{m} \mathrm{s}^{-1}\right)$ at $30 \mathrm{hPa}$ averaged over the equatorial region from the baseline (blue tones), the baseline+ozone (grey tones) and the baseline+ozone+QBO simulations (orange tones)

following way. The value at the specified height is interpolated in time between the ERA-40 monthly mean values of the adjacent mid-months which in turn had been interpolated in height between the values at the two pressure levels above and below the model's height level in question. The conversion of ERA-40 pressure levels to height values employed the mean geopotential heightat equatorial latitudes derived from the second half of the ERA-40 dataset (i.e. since 1980). A Gaussian latitudinal profile was imposed on the wind relaxation where

$\beta(\phi)=\exp \left(-\left(\frac{\phi}{25}\right)^{2}\right)$

which provides a fairly realistic latitudinal distribution confined primarily to the tropical region (see e.g. Baldwin et al. 2001). Both the choice of $\beta$ and of $\gamma$ have been empirically adjusted in order to achieve a latitudinal extent of the QBO similar to the observed one (e.g. Pascoe et al. 2005, their Fig. 5).

Figure 5 shows the time series of monthly mean zonal wind in the equatorial region at $50 \mathrm{hPa}$ from the baseline, baseline+ozone and baseline+ozone+QBO simulations. As expected, the baseline and baseline+ozone simulations have very little interannual variation and remain easterly at all times.

\section{Results}

\subsection{Temperature variability}

At $30 \mathrm{hPa}$, the time series of ensemble-mean global mean temperature of the baseline simulations (blue line in the top panel of Fig. 6) shows a rather smooth cooling only interrupted by the volcanic eruptions. In contrast, the 

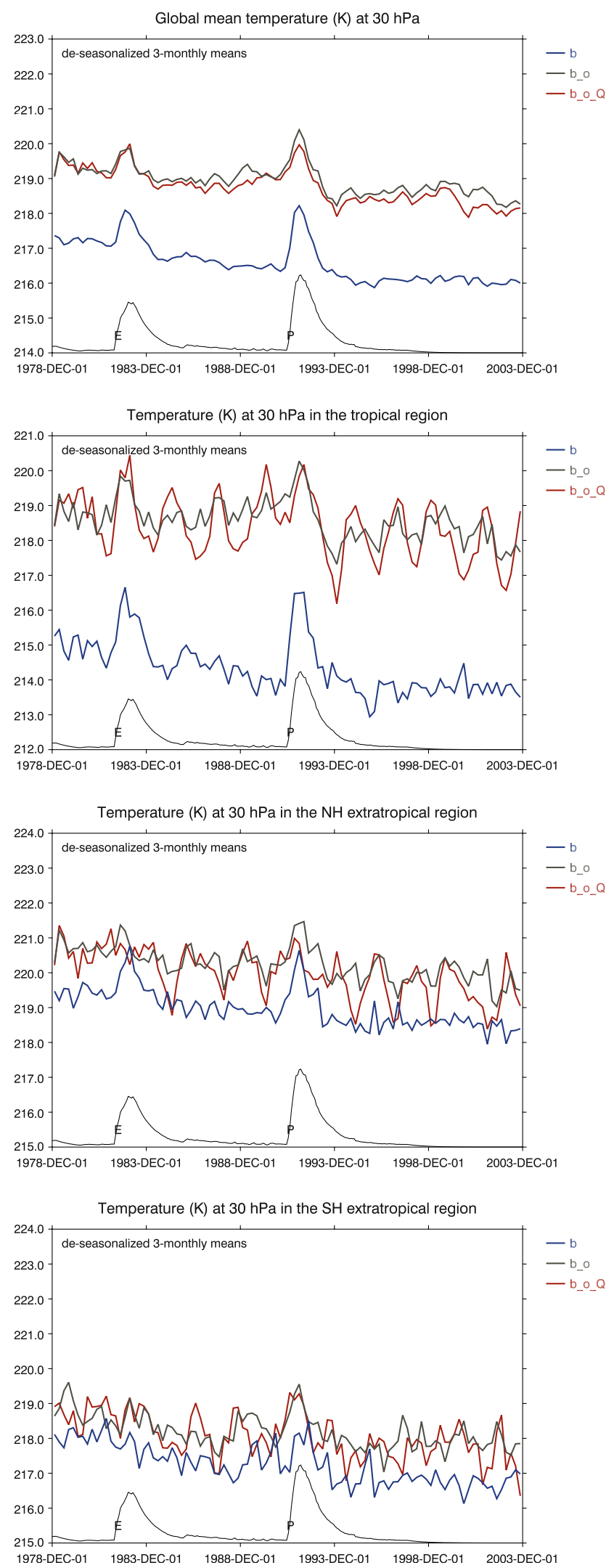

4 Fig. 6 Time series of ensemble-mean, de-seasonalized, 3-monthly mean temperature $(\mathrm{K})$ at $30 \mathrm{hPa}$ from the baseline simulations (blue line), the baseline+ozone simulation (gray line) and the baseline+ozone $+\mathrm{QBO}$ simulations (red line). Top global mean temperature. Upper middle tropical temperature. Lower middle $\mathrm{SH}$ extratropical temperature. Bottom NH extratropical temperature

baseline+ozone (grey line) and baseline+ozone+QBO simulations (red line) are characterised by a stepwise cooling. Table 1 reports the linear 7.25 year temperature trends for the two post-volcanic time periods, excluding the data from the first 2 years following the onset of the eruptions. ${ }^{4}$ In the baseline simulations, both post-eruption temperature trends are negative and correspond to the cooling rates induced by ozone depletion and changes in well-mixed greenhouse gases (Ramaswamy et al. 2006, see the WmggO3 curve in their Fig. 3b). However, the baseline+ozone and baseline+ozone + QBO simulations show positive trends, which gives rise to a step-like feature. We conduct a $t$ test to test the null hypothesis that the ensemble-mean trend of either set of perturbed simulations after the El Chichón eruption is the same as the trend in the baseline simulations. The null hypothesis can be rejected at the $5 \%$ level for the baseline+ozone simulations and at the $10 \%$ level for the 'baseline+ozone+QBO' simulations (see Table 1). In the aftermath of the Mt. Pinatubo eruption, only the baseline+ozone ensemble-mean trend is not consistent with the baseline trend (at the 5\% level).

The difference in behaviour between the baseline and baseline+ozone simulations is even more evident in the tropical region (upper middle panel of Fig. 6). The baseline simulation shows a decline between 1980 and 1995, interspersed by the volcanic responses, followed by a fairly constant value from 1995 onward. The baseline+ozone ensemble-mean, on the other hand, shows a steady increase from 1984 to 1990 and is interspersed by weaker volcanic responses. The baseline+ozone $+\mathrm{QBO}$ simulation follows the baseline+ozone simulation except with an easily identifiable QBO signal superimposed. The superposition of the El-Chichón response and a positive QBO phase is evident, which serves to enhance the peak in 1982 when compared with the baseline+ozone simulation. Similarly, the negative QBO phase in 1993 and 1994 enhances the sharp decline in the baseline+ozone simulation after the Pinatubo eruption (top and upper middle panels of Fig. 6).

In the extratropical regions (lower middle and bottom panels of Fig. 6), there is large year-to-year variability such that it is hard to see differences in the reproduction of a step-like feature. We note the presence of a QBO-like

\footnotetext{
${ }^{4}$ The first 7.25 year period covers the time period until the onset of the Mt. Pinatubo eruption.
} 
Table 1 Modelled global-mean temperature trends $\left(\mathrm{K} \mathrm{decade}^{-1}\right)$ at $30 \mathrm{hPa}$ over the 7.25 year period following major recent volcanic eruptions (the first 2 years of data after the onset of each eruption have been ignored)

\begin{tabular}{|c|c|c|c|c|c|}
\hline \multirow[t]{2}{*}{ Eruption } & \multirow{2}{*}{$\begin{array}{l}\text { Baseline } \\
30 \mathrm{hPa} \text { trend } \\
\left(\mathrm{K} \text { decade }{ }^{-1}\right)\end{array}$} & \multicolumn{2}{|c|}{ Baseline+ozone } & \multicolumn{2}{|c|}{ Baseline + ozone $+\mathrm{QBO}$} \\
\hline & & $\begin{array}{l}30 \mathrm{hPa} \text { trend } \\
\left(\mathrm{K} \mathrm{decade}{ }^{-1}\right)\end{array}$ & $\begin{array}{l}P \text { value vs. } \\
\text { baseline }\end{array}$ & $\begin{array}{l}30 \mathrm{hPa} \text { trend } \\
\left(\mathrm{K} \mathrm{decade}^{-1}\right)\end{array}$ & $\begin{array}{l}P \text { value vs. } \\
\text { baseline }\end{array}$ \\
\hline El Chichón (1982) & $-0.58 \pm 0.10$ & $0.40 \pm 0.24$ & 0.042 & $0.40 \pm 0.30$ & 0.071 \\
\hline Mt. Pinatubo (1991) & $-0.08 \pm 0.09$ & $0.59 \pm 0.18$ & 0.046 & $0.45 \pm 0.28$ & 0.188 \\
\hline
\end{tabular}

The first 7.25 years cover the time period until the onset of the Mt. Pinatubo eruption. The first column reports the eruption. The second column reports the ensemble-mean trend for the baseline simulation. The remaining columns report the ensemble-mean trends for the baseline+ozone and the baseline+ozone+QBO simulations as well as the $P$ values from a $t$ test where the null hypothesis is that the trend in the perturbed simulations is consistent with the baseline trend

signal in the baseline+ozone $+\mathrm{QBO}$ simulation in particular in the $\mathrm{NH}$ which is approximately out of phase with the signal in the tropical region. The top three panels in Fig. 7 show that the step-like cooling feature is present also in global mean temperature time series at $10 \mathrm{hPa}$ (top panel), $30 \mathrm{hPa}$ (upper middle panel, note the expanded vertical scale with regards to the top panel in Fig. 6) and $50 \mathrm{hPa}$. The step-like cooling feature is most evident at $30 \mathrm{hPa}$ and $20 \mathrm{hPa}$ (not shown). The baseline versus baseline+ozone trend differences after both volcanic eruptions are significant at the $5 \%$ level only at $30 \mathrm{hPa}$.

In the bottom panel of Fig. 7, modelled temperatures are sampled as if measured by channel 4 (T4) of the Microwave Sounding Unit (MSU) instrument. The T4 temperature obtained from the Remote Sensing Systems analysis of MSU data (Mears et al. 2003; http://www.remss.com) is also shown for comparison (thick black line). The improved ozone appears to make the absolute agreement with the MSU T4 worse. Note that this effect would be hidden if one plots only anomalies and not absolute values. Such increasing offsets do not mean that an improvement is flawed but are often associated with compensating effects and approximations made in the previous version of the model in order to achieve a better agreement with observations. Therefore we concentrate our quantitative analysis on trends, rather than absolute values. Table 2 provides the relevant trends for MSU T4 and modelled trends when temperatures are sampled according to the $\mathrm{T} 4$ weighting function. While both sets of simulations using the improved ozone data give a T4 trend after the El Chichón eruption (approximately 1984-1990) which is consistent with MSU's, the trend in the baseline simulations is significantly different at the $5 \%$ level whereby observations are treated as a single realization of the climate system in our $t$-tests (see the $t$ test description in Sect. 2.3). While the baseline simulations do not capture the observed $\mathrm{T} 4$ temperature trend after the El Chichón eruption, in the aftermath of the Mt. Pinatubo eruption (approximately 1993-1999), all three sets of simulations give T4 trends that are consistent with MSU's. Overall, the stepwise changes induced by the improved ozone dataset are most significant at $30 \mathrm{hPa}$ but the $\mathrm{T} 4$ weighting function is distributed over a rather deep layer of the atmosphere with maximum amplitude at about $55 \mathrm{hPa}$. This, together with the reduced stratospheric cooling rate since the Pinatubo eruption, are likely the main reasons why the ensemblemean trends from all sets of simulations are consistent with the observations in the 1993-2000 period.

Lanzante and Free (2008) show a systematic difference between radiosonde observations and the mean of an ensemble of GCM calculations in the period after the Mt. Pinatubo eruption, in the $100-50 \mathrm{hPa}$ layer. Since there is no apparent significant difference between MSU4 and the radiosondes in this period (Randel et al. 2009), we conclude that the model used here (HadGEM1) is performing significantly better than the ensemble-mean in Lanzante and Free (2008), even in the baseline runs. Overall, the values in Table 2 suggest that improving the ozone in the stratosphere leads to an improved modelled trend, especially over the time period 1984-1991 (when the baseline disagrees with MSU T4). This result on the possible role of ozone variability in contributing to the step-like time evolution of global mean stratospheric temperatures is supported by the recent observational study of Thompson and Solomon (2009, see their Fig. 1c).

There are a series of contenders to explain the observed stepwise cooling: the thermal inertia of the oceans following the cooling induced by volcanic aerosols, the solar cycle in irradiance, the indirect effect of volcanic eruptions and the indirect solar cycle through changes in ozone. Ramaswamy et al. (2006) imposed in their model simulations the Randel and $\mathrm{Wu}$ (2007) ozone dataset (bottom panel of Fig. 1), which included the QBO and the solar cycle signal. Ramaswamy et al. suggest (p. 1140, see their Fig. 3) that the cooler temperatures in the post-eruption years that give rise to the step-like feature in the lower stratosphere are due to a large extent to the thermal inertia of the oceans, implying a slower recovery of the surface and troposphere temperatures which in turn reduces the upwelling longwave radiation, thus cooling the lower 

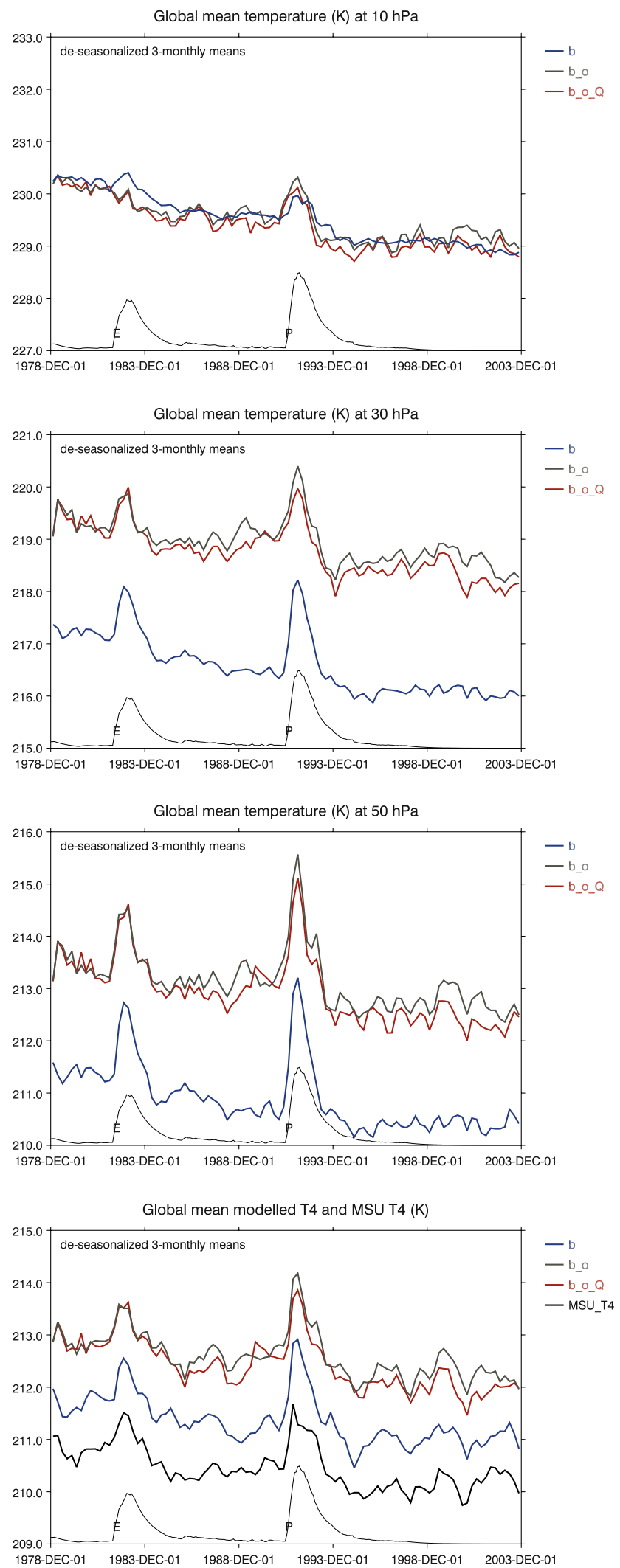

stratosphere. They also suggest that the timing of the volcanic eruptions with respect to the solar cycle is likely to be important, noting that there was a solar minimum phase in
Fig. 7 As Fig. 6 but for the time series of global mean temperature (K) at $10 \mathrm{hPa}$ (top panel), $30 \mathrm{hPa}$ (upper middle), $50 \mathrm{hPa}$ (lower middle). Note the different vertical scale with respect to Fig. 6. Bottom panel modelled temperatures sampled as if measured by channel 4 of the MSU instrument including for comparison the corresponding MSU T4 observations (thick black line) from the RSS analysis

both the post-eruption years which implies reduced shortwave heating at this time. According to Table 2, the baseline 1984-1991 trend is not consistent with the observed T4 trend, while the trends of both perturbed simulation sets are. This does not support a major contributory role to the step-like feature from either the thermal inertia of the oceans or the solar cycle in irradiance, since both factors were included in the baseline simulations.

An alternative mechanism was proposed by Thompson and Solomon (2009), who compared the observed T4 time series with both its regression onto total ozone and its residual, concluding that the step-like time evolution of global stratospheric temperatures is entirely consistent with the competing radiative and chemical effects of volcanic aerosol on stratospheric climate. Both of these effects are present in the baseline+ozone simulations, which captures the step-like feature, while the baseline simulations include only the radiative effect. This therefore suggests that the chemical (ozone) effects of the volcanic eruptions may be important. On the other hand, Ramaswamy et al. (2006) also simulated the stepwise cooling feature, even though their ozone dataset excluded the 2 years of data after each eruption. This suggests either that the chemical effect of the volcanic eruptions is not the major factor in the stepwise cooling, or that this chemical effect lasts longer than 2 years and is still strong enough to be important even after this time has elapsed. The role of volcanoes is also reinforced by consideration of the chemistry driving partitioning of $\mathrm{NO}_{2}$ and $\mathrm{NO}_{x}$ and also $\mathrm{ClO}$ and $\mathrm{Cl}_{y}$ after a volcanic eruption, which persists longer than the aerosol radiative effect (Susan Solomon, personal communication; Solomon et al. 1996, their Fig. 6; Solomon 1999, plate 6).

Finally, a third possible factor to explain the stepwise cooling feature is the 11-year solar cycle modulation of ozone that is included in the baseline+ozone simulations but is not present in the baseline simulations. Both volcanic eruptions coincided with a period of solar maximum. Ozone amounts are greater during solar maximum than solar minimum, so there is an increase during the transition from solar minimum to solar maximum (Randel and $\mathrm{Wu}$ 2007) e.g. from 1985 to 1990 and from 1995 to 2000. Temperatures will therefore increase through the associated heating and the positive temperature trend after each of the eruptions may be partly associated with this. There is also some evidence of decline in tropical temperatures in 
Table 2 Lower stratosphere T4 global-mean temperature trends $\left(\mathrm{K} \mathrm{decade}^{-1}\right)$ in the 7.25 year period following major recent volcanic eruptions (the first 2 years of data after the onset of each eruption have been ignored)

\begin{tabular}{|c|c|c|c|c|c|c|c|}
\hline \multirow[t]{2}{*}{ Eruption } & \multirow{2}{*}{$\begin{array}{l}\text { MSU } \\
\text { T4 trend } \\
\left(\mathrm{K} \text { decade }^{-1}\right)\end{array}$} & \multicolumn{2}{|l|}{ Baseline } & \multicolumn{2}{|c|}{ Baseline+ozone } & \multicolumn{2}{|c|}{ Baseline + ozone $+\mathrm{QBO}$} \\
\hline & & $\begin{array}{l}\text { T4 trend } \\
\left(\mathrm{K} \mathrm{decade}^{-1}\right)\end{array}$ & $\begin{array}{l}P \text { value vs. } \\
\text { T4 }\end{array}$ & $\begin{array}{l}\text { T4 trend } \\
\left(\mathrm{K} \mathrm{decade}^{-1}\right)\end{array}$ & $\begin{array}{l}P \text { value vs. } \\
\text { T4 }\end{array}$ & $\begin{array}{l}\text { T4 trend } \\
\left(\mathrm{K} \mathrm{decade}^{-1}\right)\end{array}$ & $\begin{array}{l}P \text { value vs. } \\
\text { T4 }\end{array}$ \\
\hline El Chichón (1982) & 0.18 & $-0.36 \pm 0.07$ & 0.017 & $0.07 \pm 0.28$ & 0.733 & $0.10 \pm 0.32$ & 0.827 \\
\hline Mt. Pinatubo (1991) & 0.05 & $0.06 \pm 0.19$ & 0.944 & $0.25 \pm 0.22$ & 0.455 & $-0.17 \pm 0.28$ & 0.515 \\
\hline
\end{tabular}

The first column reports the eruption. The second column reports the observed MSU T4 trend. The remaining columns report the ensemble-mean trends for each set of model simulations as well as the $P$ values from a $t$ test where the null hypothesis is that the modelled trend is consistent with the observed (MSU) trend

Table 3 Observed and modelled global-mean temperature trends $\left(\mathrm{K} \mathrm{decade}^{-1}\right)$ over the $1979-1999$ period

\begin{tabular}{|c|c|c|c|c|c|c|c|}
\hline \multirow{2}{*}{$\begin{array}{l}\text { Pressure } \\
\text { level (hPa) }\end{array}$} & \multirow{2}{*}{$\begin{array}{l}\text { Average sonde } \\
\text { Global trend } \\
\left(\mathrm{K} \mathrm{decade}^{-1}\right)\end{array}$} & \multicolumn{2}{|l|}{ Baseline } & \multicolumn{2}{|l|}{ Baseline+ozone } & \multicolumn{2}{|c|}{ Baseline + ozone $+\mathrm{QBO}$} \\
\hline & & $\begin{array}{l}\text { Global trend } \\
\left(\mathrm{K} \mathrm{decade}^{-1}\right)\end{array}$ & $\begin{array}{l}P \text { value vs. } \\
\text { sonde }\end{array}$ & $\begin{array}{l}\text { Global trend } \\
\left(\mathrm{K} \mathrm{decade}^{-1}\right)\end{array}$ & $\begin{array}{l}P \text { value vs. } \\
\text { sonde }\end{array}$ & $\begin{array}{l}\text { Global trend } \\
\left(\mathrm{K} \mathrm{decade}^{-1}\right)\end{array}$ & $\begin{array}{l}P \text { value vs. } \\
\text { sonde }\end{array}$ \\
\hline 30 & -0.91 & $-0.07 \pm 0.05$ & 0.004 & $-0.38 \pm 0.06$ & 0.012 & $-0.49 \pm 0.10$ & 0.052 \\
\hline 50 & -0.77 & $-0.60 \pm 0.06$ & 0.114 & $-0.42 \pm 0.07$ & 0.034 & $-0.56 \pm 0.12$ & 0.216 \\
\hline 70 & -0.65 & $-0.51 \pm 0.06$ & 0.155 & $-0.59 \pm 0.06$ & 0.441 & $-0.73 \pm 0.12$ & 0.631 \\
\hline 100 & -0.49 & $-0.24 \pm 0.05$ & 0.036 & $-0.26 \pm 0.05$ & 0.045 & $-0.34 \pm 0.09$ & 0.221 \\
\hline
\end{tabular}

The first column reports the pressure in $\mathrm{hPa}$. The second column reports the observed average radiosonde trend. The remaining columns report for each set of model simulations the ensemble-mean trend and the $P$ values resulting from a $t$ test where the null hypothesis is that the modelled trend is consistent with the observed one

the baseline+ozone after 2000, which may be associated with the transition towards solar minimum. The inclusion of the 11-year solar cycle in ozone amounts is common to both this study and the Ramaswamy et al. (2006) study, and both reproduced the stepwise cooling feature, which suggests that it may be a contributing factor. However, direct attribution would require further simulations, outside the scope of this study, in which the solar cycle signal is carefully removed from the ozone time-series employed in the baseline+ozone simulations. Eyring et al. (2006, p. 11) compared chemistry climate model hindcasts and suggested that the stepwise cooling was reproduced by those models which included the solar cycle in irradiance as well as chemical and direct radiative effects from volcanic aerosol.

The climate models assessed by the AR4 tend to overestimate the observed volcanic warming (Cordero and Forster 2006). The post-El Chichón warming of MSU T4 is about $0.80 \mathrm{~K}$ and the baseline ensemble-mean warms $0.36 \mathrm{~K}$ more than MSU T4 (see bottom panel of Fig. 7). The post-Mt. Pinatubo warming of MSU T4 is about $1.35 \mathrm{~K}$ and the baseline exceeds this figure by $0.52 \mathrm{~K}$. The magnitude of volcanic warming is reduced in the baseline+ozone simulations after both eruptions, with a difference from MSU of 0.22 and $0.29 \mathrm{~K}$ for El Chichón and Mt. Pinatubo, respectively. This shows that improving the ozone dataset may help reduce the magnitude of volcanic warming in model simulations. The warming in the baseline+ozone+QBO simulations after El Chichón is $0.35 \mathrm{~K}$ larger than in MSU's T4 and is thus greater than the baseline+ozone warming. In contrast, after Mt. Pinatubo the warming in the baseline+ozone+QBO simulations, with $0.21 \mathrm{~K}$ on top of the warming in MSU's T4, is smaller than in the baseline+ozone simulations. This is in both cases a likely effect of the temperature signal associated with the different QBO phases following the two eruptions (see also Angell 1997). This behaviour of the three sets of simulations applies to all levels from 20 to $70 \mathrm{hPa}$ (see Fig. 7). At $10 \mathrm{hPa}$, there is no warming following El Chichón in the perturbed sets of simulations and the warming following Mt. Pinatubo is similar across the three sets of simulations.

\subsection{Temperature trends}

Table 3 reports global temperature trends over the period 1979-1999 in the lower stratosphere. The trend derived from each set of simulations is compared to the observed trend, whereby temperature trends from the RATPAC-A (Free et al. 2005) and HadAT2 (Thorne et al. 2005) radiosonde observations have been averaged. Note that in this section, the time-interval, the averaging of temperature trends from the two radiosonde datasets and the averaging over latitude belts are consistent with the study by Cordero 


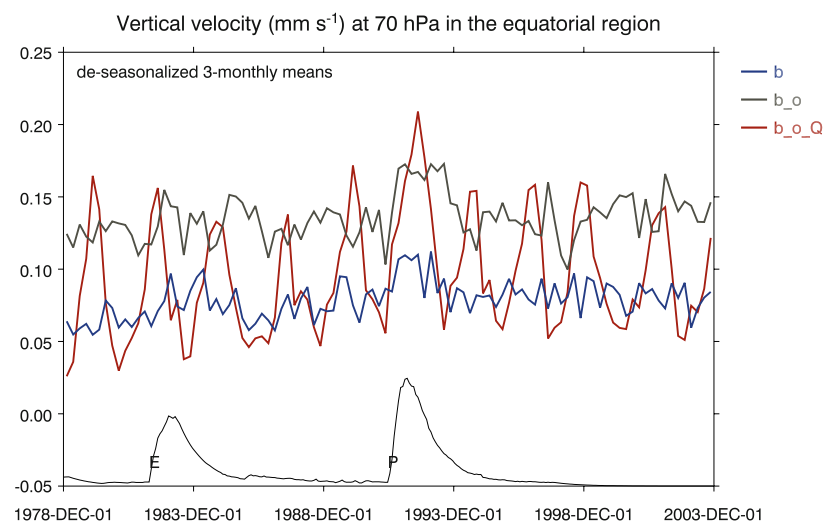

Fig. 8 As Fig. 6 but for the time series of vertical velocity $\mathrm{d} z / \mathrm{d} t$ $\left(\mathrm{mm} \mathrm{s}^{-1}\right)$ at $70 \mathrm{hPa}$ in the equatorial region
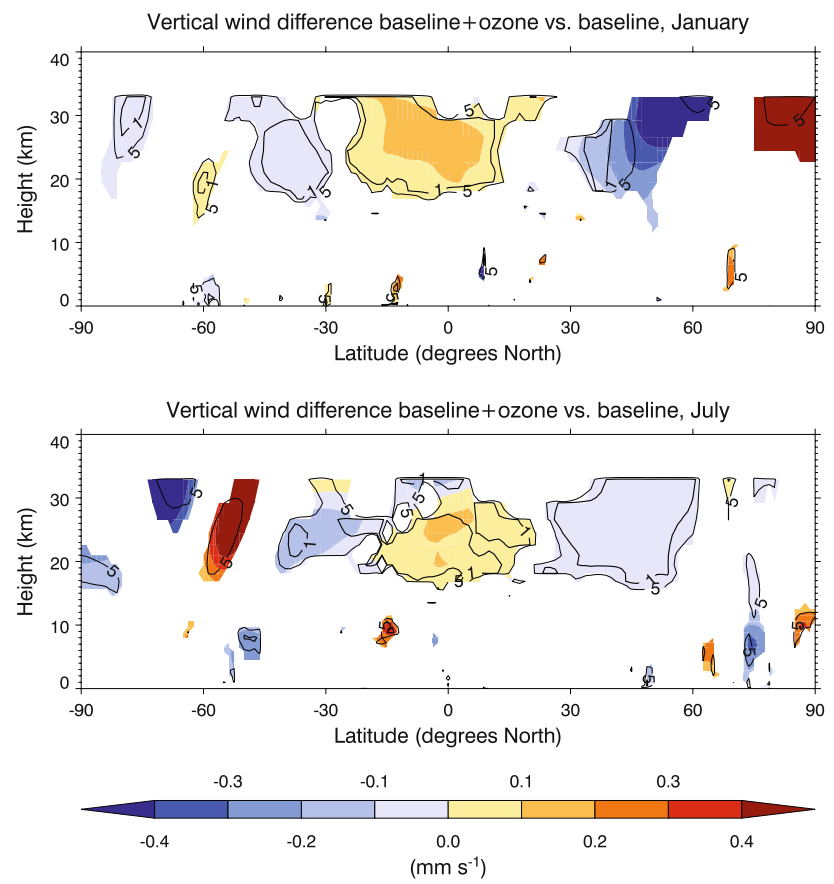

Fig. 9 As Fig. 3 but for climatological differences between the baseline+ozone and the baseline ensemble-mean zonal mean vertical velocity for January (upper panel) and July (lower) and Forster (2006; see right hand panel of their Fig. 8 and their Fig. 9). The baseline+ozone+QBO simulations do generally better than the other sets of simulations at capturing the observed trends, their trend being consistent with the observed one at all levels except $30 \mathrm{hPa}$ where the $P$ value is 0.050 . The baseline+ozone simulations improve on the baseline at all levels except $50 \mathrm{hPa}$, but their trends are consistent with the observations only at $70 \mathrm{hPa}$. The baseline simulations perform particularly badly at $30 \mathrm{hPa}$ where the baseline+ozone simulations do better although not as well as the baseline+ozone+QBO.

Table 4 reports stratospheric temperature trends in the $30^{\circ} \mathrm{S}-30^{\circ} \mathrm{N}$ region over the period $1979-1999$ in the stratosphere (as in Fig. 9 of Cordero and Forster 2006). The baseline+ozone+QBO again does best at capturing the observed trends, their trend being the only one to be consistent with the observations at all levels. The baseline simulations perform poorly.

Both globally and also in the $30^{\circ} \mathrm{S}-30^{\circ} \mathrm{N}$ region, simulated trends are smaller than those observed in every case, except at $70 \mathrm{hPa}$ in the baseline+ozone+QBO simulations. However, given that our most realistic set of simulations, the baseline+ozone $+\mathrm{QBO}$, reproduces trends that are consistent with the radiosonde trends in every case except globally at $30 \mathrm{hPa}$, it is difficult to assess whether this underestimate is meaningful at all and if it were, to what extent it is associated with observational or model uncertainties. Although large uncertainties remain due to internal variability and observational uncertainty, our study suggests that both the improved ozone dataset and the QBO relaxation have a beneficial effect on the simulation of observed trends over this time period. This is an important result in the light of Cordero and Forster's (2006) study, which showed that there are significant differences between observations and AR4 model trends, particularly in the upper tropical troposphere. This result may also be a hint that the observed trends over this particular time period may be partly subject to ozone variability and the QBO.

Table 4 Observed and modelled temperature trends $\left(\mathrm{K} \mathrm{decade}^{-1}\right)$ in the $30^{\circ} \mathrm{S}-30^{\circ} \mathrm{N}$ region over the $1979-1999$ period

\begin{tabular}{|c|c|c|c|c|c|c|c|}
\hline \multirow[t]{2}{*}{ Pressure $(\mathrm{hPa})$} & \multirow{2}{*}{$\begin{array}{l}\text { Average sonde } \\
30^{\circ} \mathrm{S}-30^{\circ} \mathrm{N} \text { trend } \\
\left(\mathrm{K} \text { decade }^{-1}\right)\end{array}$} & \multicolumn{2}{|l|}{ Baseline } & \multicolumn{2}{|l|}{ Baseline+ozone } & \multicolumn{2}{|c|}{ Baseline + ozone $+\mathrm{QBO}$} \\
\hline & & $\begin{array}{l}30^{\circ} \mathrm{S}-30^{\circ} \mathrm{N} \text { trend } \\
\left(\mathrm{K} \mathrm{decade}^{-1}\right)\end{array}$ & $\begin{array}{l}P \text { value vs. } \\
\text { sonde }\end{array}$ & $\begin{array}{l}30^{\circ} \mathrm{S}-30^{\circ} \mathrm{N} \text { trend } \\
\left(\mathrm{K} \mathrm{decade}^{-1}\right)\end{array}$ & $\begin{array}{l}P \text { value vs. } \\
\text { sonde }\end{array}$ & $\begin{array}{l}30^{\circ} \mathrm{S}-30^{\circ} \mathrm{N} \text { trend } \\
\left(\mathrm{K} \mathrm{decade}^{-1}\right)\end{array}$ & $\begin{array}{l}P \text { value vs. } \\
\text { sonde }\end{array}$ \\
\hline 30 & -0.93 & $-0.08 \pm 0.08$ & 0.008 & $-0.28 \pm 0.08$ & 0.015 & $-0.42 \pm 0.19$ & 0.120 \\
\hline 50 & -0.77 & $-0.63 \pm 0.09$ & 0.245 & $-0.33 \pm 0.08$ & 0.034 & $-0.52 \pm 0.22$ & 0.358 \\
\hline 70 & -0.64 & $-0.49 \pm 0.08$ & 0.203 & $-0.60 \pm 0.07$ & 0.615 & $-0.78 \pm 0.21$ & 0.575 \\
\hline 100 & -0.40 & $-0.08 \pm 0.05$ & 0.026 & $-0.15 \pm 0.03$ & 0.016 & $-0.23 \pm 0.12$ & 0.304 \\
\hline
\end{tabular}

The first column reports the pressure in $\mathrm{hPa}$. The second column reports the observed average radiosonde trend. The remaining columns report for each set of model simulations the ensemble-mean trend and the $P$ values resulting from a $t$ test where the null hypothesis is that the modelled trend is consistent with the observed one 


\subsection{Equatorial upwelling}

Figure 8 shows the time evolution of the ensemble-mean Eulerian vertical velocity at $70 \mathrm{hPa}$ over the equatorial region. The baseline ensemble-mean values (blue line) are at around $0.08 \mathrm{~mm} \mathrm{~s}^{-1}$. The baseline+ozone simulation shows increased values of about $0.14 \mathrm{~mm} \mathrm{~s}^{-1}$, i.e. the values are approximately doubled. The reason for such a stronger upwelling in the baseline+ozone simulations is hard to diagnose. According to Fig. 9, which shows the climatological difference in equatorial upwelling between the baseline+ozone and baseline simulations, the differences are significant and positive between 17 and $30 \mathrm{~km}$ both in January and July, with values around $0.10 \mathrm{~mm} \mathrm{~s}^{-1}$. This suggests that the increased upwelling is to some extent associated with the changed climatological distribution of ozone. This increase could be partly due to increased tropical ozone heating in these atmospheric layers and the balance between this radiative heating and upwelling in the steady thermodynamic equation. The baseline+ozone+ QBO ensemble-mean (red line) shows quasi 2-year variations that are large compared to other variability and are likely influenced by the induced meridional circulation required to maintain the temperature in thermal wind balance with the imposed QBO. We note that the $70 \mathrm{hPa}$ level $(\sim 16.9 \mathrm{~km})$ shown in Fig. 8 is about one and a half model levels below the lowest level at which the zonal wind relaxation is applied (about $18.8 \mathrm{~km}$ ) and, indeed, there is still evidence of the QBO influence as low as $85 \mathrm{hPa}$ (not shown), which illustrates the downward influence of the QBO. The baseline+ozone time series in Fig. 8 does not show such an obvious QBO variation in tropical upwelling, since the only source of this variation is through the ozone QBO which has a much weaker impact (Li et al. 1995).

Thompson and Solomon (2009) argued that changes in total ozone alone cannot account for the observed latitudinal dependence of the T4 trend over 1979-2006 and that the discrepancy is likely to arise from a positive trend in the meridional overturning circulation through wave driving. While we have seen that the change in background ozone climatology is associated with a change in equatorial upwelling, all sets of our simulations show a very small positive vertical velocity trend (Fig. 8) which are consistent with each other. Only the positive trend of the baseline is significantly different from zero and only at the $10 \%$ level ( $P$ value of 0.053$)$. While a positive trend in upwelling is expected in runs with increasing greenhouse gas forcing in the first half of the 21st century (Butchart and Scaife 2001), we do not find a robust signal in our simulations for the 1979-2005 period. Note that over such a short time period, the natural variability in the stratosphere is large compared with any potential change in overturning circulation. Overall, our results show that the improved ozone distributions do not induce significant trends in the upwelling, suggesting that any change in upwelling is unlikely to be driven solely by ozone changes, which is consistent with the conclusion of Thompson and Solomon (2009).

\section{Conclusions}

In this paper, we study the impact of improvements in the representation of ozone variability and the QBO in the stratosphere on stratospheric temperature trends in simulations of the coupled ocean atmosphere model HadGEM1 with natural and anthropogenic forcings for the 1978-2003 period. In the baseline+ozone simulations, the stratospheric zonal mean ozone climatology with superimposed trends (used in the baseline simulations) is replaced with an observed dataset including interannual variability. In addition to this, in the baseline+ozone $+\mathrm{QBO}$ simulations a QBO relaxation is applied to stratospheric zonal winds. The extent to which such improvements have influenced the lower stratosphere is examined this paper. Impacts on the tropopause layer and the troposphere below are discussed in a separate paper (Dall'Amico et al. 2009).

The stepwise cooling of the lower stratosphere observed in the aftermath of the two major recent volcanic eruptions is captured only by the perturbed sets of simulations which use the improved observed ozone dataset. A comparison of our three sets of simulations with the study by Ramaswamy et al. (2006) highlights the role of the ozone response to changes in UV radiation associated with the solar cycle in contributing to the simulation of the stepwise cooling. This effect is absent in the simulations that do not reproduce the stepwise cooling but is the main common feature across the simulations that do.

The baseline+ozone+QBO simulations do best at capturing observed temperature trends in the lower stratosphere over the 1979-1999 period, when averaged both globally and in the $30^{\circ} \mathrm{S}-30^{\circ} \mathrm{N}$ region. This highlights the role played by variability in ozone and the QBO in reducing discrepancies between models and observations although observational uncertainties and internal variability are also contributors to differences between models and observations. At the same time, this result may hint that trends over this time period are possibly subject to interannual variations in the stratosphere.

The improvements in the ozone data employed also have the effect of almost doubling the equatorial upwelling in the lower stratosphere, illustrating the sensitivity of the equatorial upwelling to the background ozone amounts. The QBO relaxation has the effect of modulating modelled lower stratospheric upwelling in the equatorial region. In agreement with Thompson and Solomon (2009), the 
observed ozone changes do not induce significant trends in the equatorial upwelling, so that the cause of any observed changes should be looked for elsewhere.

Acknowledgments Funding was provided by the UK Natural Environment Research Council. Peter Stott and Adam Scaife were supported by the Joint DECC, Defra and MoD Integrated Climate Programme-DECC/Defra (GA01101), Mod (CBC/2B/0417_Annex C5). MSU data are produced by Remote Sensing Systems and sponsored by the NOAA Climate and Global Change Program. Data are available at http://www.remss.com. We wish to thank Terry Davies, Jason Lowe, Gareth Jones, Scott Osprey, Colin Johnson, Warwick Norton, Jonathan Gregory, Peter Thorne, Eugene Cordero, Susan Solomon, Michael Ponater, Martin Dameris, Robert Sausen, Veronika Eyring, and two anonymous reviewers for their help in acquiring and processing data, their illuminating suggestions and their support. We also wish to thank all those people at the UK Met Office and various UK universities who contributed throughout the years to the development of the Hadley Centre Global Environmental Model and ancillary datasets.

\section{Appendix A: an observed ozone dataset for the 1979-2003 period for use in modelling studies}

As most coupled atmosphere-ocean climate models do not include an interactive chemistry scheme, ozone concentrations have to be externally imposed. Here, we present a zonal mean ozone distribution timeseries for the 19792003 period derived mainly from satellite observations.

For the stratosphere, the SAGE-II, MLS, HALOE and SBUV satellite instruments are the main data source. Their combination achieves data coverage over the region 215$0.1 \mathrm{hPa}$. Prior to 1985 , the only data included in the time series are from SBUV and TOMS. SBUV consists of measurements from several different satellites, and those measurements have been combined by taking into account drifts and differences between satellites (details are given in Stolarski and Frith 2006). The retrievals have been examined more recently than for SAGE-I. Hence the SBUV choice for the early period. Further, SBUV provides global coverage where there is sunlight, as opposed to one latitude for a day in a month as from SAGE (which is a solar occultation instrument). From 1985 to 1991, SAGE-II data are also included. After 1991, MLS and HALOE are added. For the period after the El Chichón eruption, SBUV data processing excluded data that was deemed aerosol contaminated, which means that some tropical data are missing for about a year after the eruption, but they are not missing globally. To make a continuous timeseries, a climatology had to be used to fill in missing data. For a 2-year period following the eruption of Mt. Pinatubo, the SAGE-II data drops out, as does some of the tropical HALOE data.

The SBUV and TOMS data are from the version 8 merged dataset (http://code916.gsfc.nasa.gov/Data_services/ merged/) which have been adjusted to account for satellite differences over the period from late 1978 to the present. At heights above $0.1 \mathrm{hPa}$ SME data are available for the period 1981-1989. Only data for the height region $0.14 \mathrm{hPa}$ to about $0.0015 \mathrm{hPa}$ were employed (SME data are available for the stratosphere but they are of poorer quality). Above $0.0015 \mathrm{hPa}$ the UK Universities Global Atmospheric Modelling Programme (UGAMP) ozone climatology (Li and Shine 1995, see http://badc.nerc.ac.uk/ data/ugamp-o3-climatology) which is valid for the period 1985-1989 was employed. It was scaled to match SME at the top of the SME range. Note that no diurnal effects were included in the data compilation. ${ }^{5}$

The first step in developing the ozone time series was the construction of a monthly mean zonal mean climato$\operatorname{logy}$ for the period $1993-2000$ with a $5^{\circ}$ resolution. Prior to merging the SAGE-II, HALOE, MLS and SBUV data to form the stratospheric component of the climatology, the data were scaled to match HALOE observations, based on comparisons when coincidences were available. Reliable satellite data go up to $0.1 \mathrm{hPa}$, essentially everything above that was based on the SME and UGAMP climatologies. Data were scaled to match HALOE because HALOE had the best overlap with all the assorted datasets. Published accuracy for all the satellite instruments is on the order of 5-10\%. The resulting changes to the SAGE values were less than $5 \%$ throughout the bulk of the stratosphere but were as much as $20 \%$ in the mesosphere at $0.1 \mathrm{hPa}$. Changes to MLS were less than 5\%, except at 0.22 and $0.32 \mathrm{hPa}$ where they were $8 \%$. Changes to SBUV were less than 3\%, except near $2 \mathrm{hPa}$ where the change was $10-20 \%$. The sign of the correction was positive for SAGE-II and MLS, and the sign varied with altitude for SBUV. This combination of SAGE-II, HALOE, MLS and SBUV data provides coverage from 215 to $0.1 \mathrm{hPa}$. SBUV data was only used as high as $1 \mathrm{hPa}$. Because SME data were not available for the 1990-2000 period, the available pre-1990 data were used and scaled to match the SAGE-II + HALOE + MLS + SBUV average at $0.1 \mathrm{hPa}$ on a globallyaveraged basis before appending to the top of the zonal climatology. Similarly, the UGAMP climatology which is valid for the period 1985-1989 was scaled to match SME at the top of the SME data range, before being appended.

\footnotetext{
5 Sunrise and sunset data from the solar occultation instruments were averaged together on a monthly basis. HALOE shows little difference between sunrise and sunset measurements. (HALOE measurements only go up to $0.1 \mathrm{hPa}$, SAGE to $\sim 0.5 \mathrm{hPa}$ ). The diurnal variation (see Allen et al. (1984), is modelled to be $\sim 10 \%$ at $50 \mathrm{~km}(1 \mathrm{hPa}), 25 \%$ at $60 \mathrm{~km}$ (near $0.1 \mathrm{hPa}$ ) and $40 \%$ at $80 \mathrm{~km}$ (near $0.01 \mathrm{hPa}$ ). The published accuracy for the solar occultation instruments is 5-10\%. Rusch et al. (1990) compared SME (with a varying time of observation) and SAGE II sunset values at $1 \mathrm{hPa}$ and dealt with the diurnal correction, and found a maximum correction of $6 \%$ in summer (with the solar occultation measurement higher than the daytime measurement).
} 
The UGAMP climatology used SBUV, SAGE II, SME airglow and TOMS, and ozonsondes, and was valid for 1985-1989. Shifts were just applied to make the two averages consistent. The SME yearly average climatology was based on all the SME data available (both airglow and UV instruments), the satellite ran from 1981-1989. Below $215 \mathrm{hPa}$, a scaled version of the KNMI (The Royal Dutch Meteorological Institute, Dutch: Koninklijk Nederlands Meteorologisch Instituut) climatology (Fortuin and Kelder 1998) was appended and then additionally adjusted to match the climatological total column ozone for the 1990s from the TOMS instrument.

Once the monthly mean climatology was developed, the time series could be constructed. Firstly, the SAGE-II, HALOE, SBUV and MLS data were binned on a $5^{\circ}$ latitude grid, and then averaged on a monthly basis. After doing this, there were many points with missing data. Initial filling was done via interpolation across latitude or time if only one point was missing between two points with data. With more missing points, the climatology was used to fill in, scaled based on the ratio between the endpoints of the existing data and the climatology. For example, if March and April 1993 were missing, then the climatology was multiplied by the ratio of February and May 1993 with the February and May climatology and the resulting values used. Polar regions were filled in using the previously constructed climatology scaled by the observed total ozone for any given month from TOMS. Above $1 \mathrm{hPa}$, the climatology was scaled according to the ratio of the observed column between 1 and $2 \mathrm{hPa}$ and the climatological column between 1 and $2 \mathrm{hPa}$. The troposphere was filled in by scaling the mean climatology to match the deficit in ozone column needed to match the TOMS data. The whole dataset was then checked on a profile-by-profile basis looking for discontinuities, and those found were adjusted, keeping the column within 3\% of the observed TOMS column. As for the vertical coordinate system, the original coordinate for the ozone measurements varies according to the instrument. Initially there were pressure data for MLS, HALOE and SBUV, and altitude data (including pressure information) for SAGE II. Before combining datasets, everything was put on a set of standard pressure levels that corresponded with the UARS (Upper Atmosphere Research Satellite) standard pressure levels used by MLS and HALOE. The altitude range is from the surface to $0.01 \mathrm{hPa}$ for the total combined set. Pressure ranges vary for the different instruments used.

\section{Appendix B: preparation of the improved ozone dataset}

For the perturbed sets of simulations, the tropospheric component of the dataset described in Appendix A below the WMO tropopause has been overwritten using the corresponding values employed in the baseline simulations (described in Sect. 2.2 and in Stott et al. 2006). This ensures that only changes in the stratosphere were imposed.

The resulting dataset was then converted to the heightbased hybrid vertical coordinate of the model (see Table 2 of Martin et al. 2006), using the SPARC temperature climatology (Randel et al. 2004, available online on http:// www.sparc.sunysb.edu/html/temp_wind.html) and finally the data were sampled at the appropriate model levels.

Note that vertical interpolations make use of the hydrostatic equation and require knowledge and/or assumptions about the temperature profile. There are simpler approximations than the one employed as e.g. assuming an isothermal atmosphere, which implies a constant scale height. In a standard atmosphere, temperature varies only with height but not with latitude or season. Here, we used the SPARC temperature profile climatology. Possible errors introduced by the simpler approach of using the International Standard Atmosphere (ISA, see http:// en.wikipedia.org/wiki/International_Standard_Atmosphere) for the January climatology reach about $+40 \%$ near the equator in the lowermost stratosphere (not shown) and $-40 \%$ at high latitudes in the $\mathrm{NH}$ (winter hemisphere) in the upper troposphere and lower stratosphere. Potentially, biases may be introduced also by neglecting large trends in the vertical temperature profile. Such errors can induce differences in diabatic warming rates and hence temperature and wind perturbations. Although we do not test the resulting impact of applying any simplifying assumption here, the above figures call for caution in choosing an appropriate method for vertical interpolation of ozone distributions and suggest that the description of a new dataset should report the assumptions made.

The ozone amounts residing above the top of the model lid at about $5 \mathrm{hPa}$ were discarded, which accounts for about 10-20 DU contribution to the total column of about 300 DU. While this treatment follows current practice, and indeed a similar treatment was carried out in the preparation of the 'baseline' ozone treatment, the discarding of ozone amounts will inevitably cause errors in the diabatic warming estimates, which are not straightforward to assess since ozone is active at both short and long wavelengths. The authors are not aware of any investigation of the error caused by this omission. While one might consider redistributing the discarded ozone amounts within the top few levels of the model, the height profile of such a redistribution would need careful consideration as it is likely to significantly perturb the diabatic warming profile. Indeed, this redistribution would lead to a systematic overestimate of the solar heating, because the ozone would lead to absorption of more solar radiation at altitudes that it would not ordinarily be absorbed, as it would not be "sheltered" 
by the absorption of solar radiation by ozone in the upper stratosphere. Also, by replacing the stratospheric component of the imposed ozone fields with the new improved dataset, the total column amounts in the baseline and the perturbed simulations will not be identical.

\section{References}

Allen MJ, Lunine JI, Yung YL (1984) The vertical distribution of ozone in the mesosphere and lower thermosphere. Geophys Res Lett 89:4841-4872

Angell JK (1997) Stratospheric warming due to Agung, El Chichon, and Pinatubo taking into account the quasi-biennial oscillation. J Geophys Res 102:9479-9485. doi:10.1029/96JD03588

Austin J, Tourpali K, Rozanov E, Akiyoshi H, Bekki S, Bodeker G, Bruhl C, Butchart N, Chipperfield M, Deushi M, Fomichev VI, Giorgetta MA, Gray L, Kodera K, Lott F, Manzini E, Marsh D, Matthes K, Nagashima T, Shibata K, Stolarski RS, Struthers H, Tian W (2008) Coupled chemistry climate model simulations of the solar cycle in ozone and temperature. J Geophys Res 113:D11306. doi:10.1029/1007JD009391

Baldwin MP, Gray LJ, Dunkerton TJ, Hamilton K, Haynes PH, Randel WJ, Holton JR, Alexander MJ, Hirota I, Horinouchi T, Jones DBA, Kinnersley JS, Marquardt C, Sato K, Takahashi M (2001) The quasi-biennial oscillation. Rev Geophys 39:179-229. doi:10.1029/1999RG000073

Baldwin MP, Stephenson DB, Thompson DWJ, Dunkerton TJ, Charlton AJ, O'Neill A (2003) Stratospheric memory and skill of extended-range weather forecasts. Science 301:636-640. doi: $10.1126 /$ science. 1087143

Butchart N, Scaife AA (2001) Removal of chlorofluorocarbons through increased mass exchange between the stratosphere and troposphere in a changing climate. Nature 410:799-802. doi: $10.1038 / 35071047$

Collimore CC, Hitchman M, Martin DW (1998) Is there a quasibiennial oscillation in tropical deep convection? Geophys Res Lett 25:333-336. doi:10.1029/97GL03722

Collimore CC, Martin DW, Hitchman M, Huesmann A, Waliser D (2003) On the relationship between the QBO and tropical deep convection. J Clim 16:2552-2568. doi:10.1175/1520-0442 (2003)016<2552:OTRBTQ > 2.0.CO;2

Collins WJ, Stevenson DS, Johnson CE, Derwent RG (1997) Tropospheric ozone in a global-scale three-dimensional Lagrangian model and its response to $\mathrm{NO}_{\mathrm{x}}$ emission controls. J Atmos Chem 26:223-274

Cordero EC, Forster PMF (2006) Stratospheric variability and trends in models used for he IPCC AR4. Atmos Chem Phys 6:53695380

Coughlin K, Tung KK (2001) QBO signals found at the extratropical surface through Northern annular Modes. Geophys Res Lett 28:4563-4566. doi:10.1029/2001GL013565

Crooks S, Gray LJ (2005) Characterization of the 11-year solar signal using a multiple regression analysis of the ERA-40 dataset. J Clim 18:996-1015. doi:10.1175/JCLI-3308.1

Dall'Amico M, Egger J (2007) Empirical master equations. Part II: application to stratospheric QBO, solar cycle, and northern annular mode. J Atmos Sci 64:2996-3015. doi:10.1175/ JAS3993.1

Dall'Amico M, Stott PA, Scaife AA, Gray LJ, Rosenlof KH, Karpechko AY (2009) Impact of stratospheric variability on tropospheric climate change. Clim Dyn. doi:10.1007/s00382009-0580-1
Daniel JS, Solomon S, Albritton DL (1995) On the evaluation of halocarbon radiative forcing and global warming potentials. J Geophys Res 100:1271-1285. doi:10.1029/94JD02516

Eyring V, Butchart N, Waugh DW, Akiyoshi H, Austin J, Bekki S, Bodeker GE, Boville BA, Brühl C, Chipperfield MP, Cordero E, Dameris M, Deushi M, Fioletov VE, Frith SM, Garcia RR, Gettelman A, Giorgetta MA, Grewe V, Jourdain L, Kinnison DE, Mancini E, Manzini E, Marchand M, Marsh DR, Nagashima T, Newman PA, Nielsen JE, Pawson S, Pitari G, Plummer DA, Rozanov E, Schraner M, Shepherd TG, Shibata K, Stolarski RS, Struthers H, Tian W, Yoshiki M (2006) Assessment of temperature, trace species, and ozone in chemistry climate model simulations of the recent past. J Geophys Res 111:D22308. doi: 10.1029/2006JD007327

Fortuin JPF, Kelder H (1998) An ozone climatology based on ozonesonde and satellite measurements. J Geophys Res 103:21709-31734

Free M, Seidel DJ, Angell JK, Lanzante J, Durre I, Peterson TC (2005) Radiosonde atmospheric temperature products fro assessing climate (RATPAC): a new dataset of large-area anomaly time series. J Geophys Res 110:D22101. doi:10.1029/2005JD006169

Gillett NP, Thompson WJ (2003) Simulation of recent southern hemisphere climate change. Science 302:273-275. doi:10.1126/ science. 1087440

Giorgetta MA, Bengtsson L, Arpe K (1999) An investigation of QBO signals in the east Asian and Indian monsoon in GCM experiments. Clim Dyn 15:435-450. doi:10.1007/s003820050292

Gray LJ, Pyle JA (1989) A two dimensional model of the quasibiennial oscillation of ozone. J Atmos Sci 46:203-220. doi: 10.1175/1520-0469(1989)046<0203:ATDMOT>2.0.CO;2

Gray LJ, Ruth S (1993) The modelled latitudinal distribution the ozone quasi-biennial oscillation using observed equatorial winds. J Atmos Sci 50:1033-1046. doi:10.1175/1520-0469 (1993) $050<1033$ :TMLDOT $>2.0$. CO;2

Gray LJ, Rumbold ST, Shine KP (2009) Stratospheric temperature and radiative forcing response to 11-year solar cycle changes in irradiance and ozone. J Atmos Sci. doi:10.1175/2009JAS2866.1

Haigh JD (2003) The effects of solar variability on the Earth's climate. Philos Trans R Soc Lond 361:95-111. doi:10.1098/rsta. 2002.1111

Haigh JD, Blackburn M, Day R (2005) The response of tropospheric circulation to perturbations in lower stratospheric temperature. J Clim 18:3672-3685. doi:10.1175/JCLI3472.1

Hamilton K (1998) Effects of an imposed quasi-biennial oscillation in a comprehensive troposphere-stratosphere-mesosphere general circulation model. J Clim 55:2393-2418

Heath DF, Krueger AJ, Roeder HR, Henderson BD (1975) The solar backscatter ultraviolet and total ozone mapping spectrometer (SBUV/TOMS) for Nimbus G. Opt Eng 14:323-331

Intergovernmental Panel on Climate Change (2007) The physical science basis: working group I contribution to the fourth assessment report of the IPCC, Cambridge University Press, London

Johns TC, Durman CF, Banks HT, Roberts MJ, McLaren AJ, Riddley JK, Senior CA, Williams KD et al (2006) The new Hadley Centre climate model (HadGEM1). Evaluation of coupled simulations. J Clim 19:1327-1353. doi:10.1175/JCLI3712.1

Karoly (2000) Stratospheric aspects of climate forcing. SPARC Newsletter 14. http://www.atmosp.physics.utoronto.ca/SPARC/ News14/14_Karoly.html

Kiehl JT, Schneider TL, Poltmann RW, Solomon S (1999) Climate forcing due to tropospheric and stratospheric ozone. J Geophys Res 104(31):239-254

Lanzante JR, Free M (2008) Comparison of radiosonde and GCM vertical temperature trend profiles: effects of dataset choice and data homogenization. J Clim 21:5417-5435. doi:10.1175/ 2008JCLI2287.1 
Lean J, Beer J, Bradly R (1995) Reconstruction of solar irradiance since 1610: implications for climate change. Geophys Res Lett 22:3195-3198. doi:10.1029/95GL03093

Li D, Shine KP (1995) A 4-dimensional ozone climatology for UGAMP models UK Universities global atmospheric modelling programme internal report No. 35

Li D, Shine KP, Gray LJ (1995) The role of ozone-induced diabatic heating anomalies in the quasi-biennial oscillation. Q J R Meteorol Soc 121:937-943. doi:10.1002/qj.49712152411

Livesey NJ, Read WG, Froidevaux L, Waters JW, Pumphrey HC, Wu DL, Santee ML, Shippony Z, Jarnot RF (2003) The UARS Microwave limb sounder version 5 dataset: Theory, characterization and validation. J Geophys Res 108(D13):4378. doi: 10.1029/2002JD002273

Martin GM, Ringer MA, Pope VD, Jones A, Dearden C, Hinton TJ (2006) The Physical properties of the atmosphere in the new Hadley Centre global environmental model (HadGEM1). Part I: model description and global climatology. J Clim 19:1274-1301. doi:10.1175/JCLI3636.1

McCormick MP, Zawodny JM, Viega RE, Larson JC, Wang PH (1989) An overview of SAGE I and II ozone measurements. Planet Space Sci 37:1567-1586. doi:10.1016/0032-0633(89) 90146-3

Mears CA, Schabel MC, Wentz FJ (2003) A reanalysis of the MSU Channel 2 tropospheric temperature record. J Clim 16:3650-3664. doi:10.1175/1520-0442(2003)016<3650:AROTMC $>2.0 . C O ; 2$

Montzka SA, Butler JH, Elkins JW, Thompson TM, Clarke AD, Lock LT (1999) Present and future trends in the atmospheric burden of ozone-depleting halogens. Nature 398:690-694. doi:10.1038/ 19499

Nakicenovic N, Swart R (eds) (2000) Emission scenarios. Cambridge University Press, London, $570 \mathrm{pp}$

Pascoe CL, Gray LJ, Crooks SA, Juckes MN, Baldwin MP (2005) The quasi-biennial oscillation: Analysis using ERA-40 data. J Geophys Res 110:D08105. doi:10.1029/2004JD004941

Pawson S, Labitzke K, Leder S (1998) Stepwise changes in stratospheric temperature. Geophys Res Lett 25:2157-2160. doi: 10.1029/98GL51534

Ramaswamy V, Schwarzkopf MD, Randel WJ, Santer BD, Soden BJ, Stenchikov GL (2006) Anthropogenic and natural influences in the evolution of lower stratospheric cooling. Science 311:11381141. doi: $10.1126 /$ science. 1122587

Randall DA, Wood RA, Bony S, Colman R, Fichefet T, Fyfe J, Kattsov V, Pitman A, Shukla J, Srinivasan J, Stouffer RJ, Sumi A, Taylor KE (2007) Climate models and their evaluation. In: Solomon S, Qin D, Manning M, Chen Z, Marquis M, Averyt KB, Tignor M, Miller HL (eds) Climate change 2007: the physical science basis. Contribution of working group I to the fourth assessment report of the intergovernmental panel on climate change. Cambridge University Press, Cambridge

Randel WJ, Wu F (1995) TOMS total ozone trends in potential vorticity coordinates. Geophys Res Lett 22:683-686. doi: 10.1029/94GL02790

Randel WJ, Wu F (1999) A stratospheric ozone trends dataset for global modelling. Geophys Res Lett 26:3089-3092. doi:10.1029/ 1999GL900615

Randel WJ, Wu F (2007) A stratospheric ozone profile data set for 1979_ 2005: variability, trends, and comparisons with column ozone data. J Geophys Res 112:D06313. doi:10.1029/2006JD007339

Randel WJ, Stolarski RS, Cunnold DM, Logan JA, Newchurch MJ, Zawodny JM (1999) Trends in the vertical distribution of ozone. Science 285:1689-1692. doi:10.1126/science.285.5434.1689

Randel W, Petra U, Fleming EricF, Geller M, Marvin GelmanM, Hamilton K, Karoly D, Ortland D, Pawson S, Swinbank R, Wu F, Baldwin M, Chanin M-L, Keckhut P, Labitzke K, Remsberg E, Simmons A, Wu D (2004) The SPARC intercomparison of middle atmosphere climatologies. J Clim 17:986-1003. doi: 10.1175/1520-0442(2004)017<0986:TSIOMC $>2.0$. CO;2

Randel WJ, Shine KP, Austin J, Barnett J, Claud C, Gillett NP, Keckhut P, Langematz U, Lin R, Long C, Mears C, Miller A, Nash J, Seidel DJ, Thompson DWJ, Wu F, Yoden S (2009) An update of observed stratospheric temperature trends. J Geophys Res 114:D02107. doi:10.1029/2008JD010421

Ringer MA, Martin G, Greeves C, Hinton T, Inness P, James P, Pope V, Scaife AA, Slingo J, Stratton R, Yang G (2006) The physical properties of the atmosphere in the New Hadley Centre global atmospheric model (HadGEM1): Part II: global variability and regional climate. J Clim 19:1302-1326. doi:10.1175/JCLI3713.1

Rusch DW, Mount GH, Barth CA, Thomas RJ, Callan MT (1984) Solar mesosphere explorer ultraviolet spectrometer-measurements of ozone in the $1.0-0.1 \mathrm{hPa}$ region. J Geophys Res 89:1677-1687. doi:10.1029/JD089iD07p11677

Rusch DW, Clancy RT, Mccormick MP, Zawodny JM (1990) A comparison of solar mesosphere explorer and stratosphere aerosol and gas experiment II ozone densities near the stratopause. J Geophys Res 95:3533-3537. doi:10.1029/JD095iD04p03533

Russell JM, Gordley LL, Park JH, Drayson SR, Hesketh DH, Cicerone RJ, Tuck AF, Frederick JE, Harries JE, Crutzen PJ (1993) The halogen occultation experiment. J Geophys Res 98(10):777-797

Santer BD, Wehner MF, Wigley TML, Sausen R, Meehl GA, Taylor KE, Ammann C, Arblaster J, Washington WM, Boyle JS, Bruggemann W (2003) Contributions of anthropogenic and natural forcings to recent tropopause height changes. Science 301:479-483. doi:10.1126/science. 1084123

Sato M, Hansen JE, McCormick MP, Pollack JB (1993) Stratospheric aerosol optical depths (1850-1990). J Geophys Res 98:2298722994. doi:10.1029/93JD02553

Sato M, Hansen J, Lacis A, Thomason L (2002) Stratospheric aerosol optical thickness NASA GISS datasets and images. http:// www.giss.nasa.gov/modelforce/strataer/

Seidel DJ, Lanzante JR (2004) An assessment of three alternatives to linear trends for characterizing global atmospheric temperature changes. J Geophys Res 109:D14108. doi:10.1029/2003JD004414

Seidel DJ, Randel WJ (2006) Variability and trends in the global tropopause estimated from radiosonde data. J Geophys Res 111. doi:10.1029/2006JD007363

Shine KP, Bourqui MS, Forster PM F, Hare SHE, Langematz U, Braesicke P, Grewe V, Ponater M, Schnadt C, Smith CA, Haigh JD, Austin J, Butchart N, Shindell DT, Randel WJ, Nagashima T, Portman RW, Solomon S, Seidel DJ, Lanzante J, Klein S, Ramaswamy V, Schwarzkopf MD (2003) A comparison of model-simulated trends in stratospheric temperature. Q J R Meteorol Soc 129:1565-1588. doi:10.1256/qJ02.186

Solanki SK, Krivova NA (2003) Can solar variability explain global warming since 1970? J Geophys Res 108(5):1200. doi:10.1029/ 2002JA009753

Solomon S (1999) Stratospheric ozone depletion: a review of concepts and history. Rev Geophys 37(3):275-316

Solomon S, Portmann RW, Garcia RR, Thomason LW, Poole LR, McCormick MP (1996) The role of aerosol variations in anthropogenic ozone depletion at northern midlatitudes. J Geophys Res 101:6713-6727

Stenchikov G, Hamilton K, Robock A, Ramaswamy V, Schwarzkopf MD (2004) Arctic oscillation response to the 1991 Pinatubo eruption in the SKyHI general circulation model with a realistic quasi-biennial oscillation. J Geophys Res 109. doi:10.1029/ 2003JD003699

Stenchikov G, Hamilton K, Stouffer RJ, Robock A, Ramaswamy V, Santer B, Graf H-F (2006) Climate impacts of volcanic eruptions in the IPCC AR4 climate models. J Geophys Res 111:D07107. doi:10.1029/2005JD006286 
Stolarski RS, Frith SM (2006) Search for evidence of trend slowdown in the long-term TOMS/SBUV total ozone data record: the importance of instrument drift uncertainty. Atmos Chem Phys 6:4057-4065

Stott PA, Tett SFB, Jones GS, Allen MR, Ingram WJ, Mitchell JFB (2001) Attribution of twentieth century temperature change to natural and anthropogenic causes. Clim Dyn 17:1-21. doi: 10.1007/PL00007924

Stott PA, Jones GS, Mitchell JFB (2003) Do models underestimate the solar contribution to recent climate change? J Clim 16:4079-4093. doi:10.1175/1520-0442(2003)016<4079:DMUTSC >2.0.CO;2

Stott PA, Jones GS, Lowe JA, Thorne P, Durman C, Johns TC, Thelen J-C (2006) Transient climate simulations with the HadGEM1 climate model: causes of past warming and future climate change. J Clim 19:2763-2782. doi:10.1175/JCLI3731.1

Thomas RJ, Barth CA, Rusch W, Sanders RW (1984) Solar mesosphere explorer near-infrared spectrometer-measurements of 1.27-micron radiances and the inference of mesospheric ozone. J Geophys Res 89:9569-9580. doi:10.1029/JD089iD06p09569

Thompson DWJ, Solomon S (2002) Interpretation of recent Southern Hemisphere climate change. Science 296:895-899. doi:10.1126/ science. 1069270

Thompson DWJ, Solomon S (2009) Understanding recent stratospheric climate change. J Clim 22:1934-1943. doi:10.1175/ 2008JCLI2482.1
Thompson DWJ, Wallace JM (2000) Annular modes in the extratropical circulation Part I: month-to-month variability. J Clim 13:1000-1016. doi:10.1175/1520-0442(2000)013<1000: AMITEC $>2.0 . \mathrm{CO} ; 2$

Thorne PW, Parker DE, Tett SFB, Jones PD, McCarthy M, Coleman $\mathrm{H}$, Brohan P (2005) Revisiting radiosonde upper air temperature from 1958 to 2002. J Geophys Res 110:D18105. doi:10.1029/ 2004JD005753

Uppala SM, Kållberg PW, Simmons AJ, Andrae U, Bechtold VD, Fiorino M, Gibson JK, Haseler J, Hernandez A, Kelly GA, Li X, Onogi K, Saarinen S, Sokka N, Allan RP, Andersson E, Arpe K, Balmaseda MA, Beljaars ACM, Van De Berg L, Bidlot J, Bormann N, Caires S, Chevallier F, Dethof A, Dragosavac M, Fisher M, Fuentes M, Hagemann S, Holm E, Hoskins BJ, Isaksen L, Janssen PAEM, Jenne R, McNally AP, Mahfouf JF, Morcrette JJ, Rayner NA, Saunders RW, Simon P, Sterl A, Trenberth KE, Untch A, Vasiljevic D, Viterbo P, Woollen J (2005) The ERA-40 re-analysis. Q J R Meteorol Soc 131:2961-3012. doi:10.1256/ qj.04.176

von Storch H, Zwiers FW (1999) Statistical analysis in climate research. Cambridge University Press, London 